\title{
THE DISSEMINATION OF LISTER'S TEACHING IN SPAIN*
}

by

\author{
JUAN RIERA
}

\section{INTRODUCTION}

THE establishment of the 'antiseptic principle' as the foundation of modern, safe surgery, is a direct result of the work and teaching of Joseph Lister (1827-1912). The international conference organized by the Royal College of Surgeons of England in 1967, to mark the centenary of Lister's initial publication on antisepsis, discussed, among many other topics, the spread and influence of Listerism in Europe. Nobody, however, has yet studied the dissemination and influence of Listerian principles in Spain, and the following paper is the first attempt to survey this theme.

The details of Lister's career are so well known that we may begin by considering Lister's most important papers, in which we see a progressive concern with the serious problem of frequent hospital infections in wounds. Beginning with his initial studies of inflammation (1858) ${ }^{155}$ his later work on the antiseptic method was a logical continuation and his paper on A New Method of Treating Compound Fracture, Abscess, etc. (1867) $)^{157}$ is the first contribution to the antiseptic era of surgery that Lister continued to elaborate in successive stages.

Of what historical importance is the discovery of Lister? Two facts are sufficient to show the real extent of this discovery. First, general surgery was almost entirely transformed; and second, new and growing surgical specialities could now exploit very much wider technical possibilities. The most spectacular results were those obtained in cases of lesions caused by compound or complicated fractures; the formation of pus and septicaemia, which hitherto had been the cause of nearly 50 per cent of deaths, was no longer a danger.

The teaching of Pasteur on fermentation is the basis of the initial ideas of Listerism as a scientific theory. In fact, it would not be an exaggeration to say that surgical antisepsis was the application of the postulates of Pasteur to the field of surgical empiricism. Pasteur had shown that fermentation and decomposition are caused by living micro-organisms. Lister was able to relate this teaching to the actual problem faced by surgery in his day, namely the serious and frequent hospital infections. In 1861 Lister stated that suppuration is caused by the decomposition of wounds. Pasteur had demonstrated that decomposition was caused by micro-organisms, and Lister deduced that suppuration had a bacterial aetiology. He then tried to find means that would prevent this pathological process. Faced with the concept of Pus bonum et laudabile he recommended using energetic antiseptic methods, consisting fundamentally of the use of carbolic acid. As we have already stated, without a previous acceptance of the theory of bacteria it would have been impossible to obtain a scientific formulation of the postulates of Lister. We must consider Lister to be not

\footnotetext{
* The research for this paper was made possible by a grant from the Wellcome Trust, for which the author is pleased to record his thanks. The present paper is an abridged English translation of a more extensive study in Spanish.
} 


\section{Juan Riera}

only the discoverer of antisepsis, but, and this is much more important, the creator of the surgical theory that was given the name of Listerism.

Other surgeons had employed antiseptic substances, such as carbolic acid. We would mention Guérin, Bottini and Lemaire, who had carried out experiments without any theoretical basis. The method of Lister contains much more, and the use of carbolic acid was only a practical consequence. His most important contribution was in the field of surgical pathology, since with the lapse of time the original method used and recommended by Lister was markedly amplified and perfected, although the theoretical basis always remained the same. In fact, asepsis and antisepsis are the same thing; one is an improvement on the other. It would be idle to pretend that the asepsis of Bergmann was theoretically distinct from the Listerian approach of fighting the infective processes in wounds and surgical operations.

The fundamental postulate of Listerism may be summarized as follows: keeping the wound clean by means of suitable pads impregnated with carbolic acid, followed by the placement of a dressing on the wound, soaked in this substance, and then the prevention of evaporation by covering with some impermeable material. These dressings were fixed with adhesives and from time to time carbolic acid was applied to the wound. These simple rules enabled the wounds to heal without suppuration and in the first thirteen cases of compound fractures there was a death rate of less than 15 per cent.

In the face of such surprising results Lister's method rapidly gained fervent supporters, although it might seem strange that British surgeons were those who most resisted these new ideas. One of the first adherents of Lister's system was the Danish professor Saxtorph, who, in 1870 became an advocate of the antiseptic method. Within a short time practically the entire body of German surgeons accepted these ideas; Richard von Volkmann, nominated Halle Professor in 1867, studied the work of Lister and became one of his most ardent defenders. These ideas were accepted by Hagedorm in Magdeburg, Nussbaum in Munich and Bardeleben in Berlin. A little later Ernst von Bergmann in Berlin developed a notable improvement, inventing asepsis, or the 'aseptic method'. To this important list we could add the names of other German surgeons, such as Gustav Neuber in Kiel, and Theodor Billroth in Vienna. Neuber insisted especially on the necessity of putting into practice the asepsis technique. He is the author of the prolonged method of treatment, consisting fundamentally of aseptic healing with the least possible use of antiseptics. Lucas Championnière was a protagonist of Listerism in France and he may be considered to be the initiator of the antiseptic method in that country. Other French surgeons who accepted the teaching of Lister were Ollier and Létiévant in Lyons, and Gross in Nancy. Margary and Novaro in Turin were the main supporters of the Listerian method in Italy.

However, some British surgeons, such as Simpson, Lawson Tait, and Spencer Wells showed great resistance to the teaching of Lister. Sir James Young Simpson clashed with Lister in a bitter argument that degenerated into personal attacks on each other. Hughes Bennett, Professor of Physiology at Edinburgh, and Sir James Paget of St. Bartholomew's Hospital, as well as Nunneley, tried in every way to discredit antisepsis. In France, Guérin especially was against Listerism and he liked to com- 


\section{The Dissemination of Lister's Teaching in Spain}

pare his poor resources, the so-called 'Cotton-wool cure', with the method of Lister.

The final triumph of Lister in Europe can be pinpointed to one date. Young British surgeons raised their voices in support of Lister, among them Sir Watson Cheyne, Joseph Bell and Berkeley Hill, who became converts to antisepsis. Then, faced with such irrefutable facts as the operation on a large scapular tumour without suppuration, Sir James Paget and Sir Prescott Harriet, who had refused to operate, had to give way before the evidence. Lister's final triumph may be put down to 1879 , when the International Congress of Medical Sciences in Amsterdam, attended by surgeons from London, acclaimed Lister. From then to his death in 1912, Lord Lister lived with the highest honours and his scientific work is without dispute most important in the history of surgery.

\section{SPANISH SURGERY DURING THE NINETEENTH CENTURY}

We outline here the situation in which Spanish medicine, and especially surgery, found itself when confronted with the new surgical method created by Lister. We thus hope to understand better the ways in which Lister's antiseptic method was disseminated in Spain.

There are three stages in the development of Spanish medical knowledge during the nineteenth century. The first begins from the War of Independence up to the end of the reign of Ferdinand VII (1833). This period represents a fall in the very high level reached by Spanish medicine during the last years of the age of enlightenment. Surgery shows a very similar picture. Generally the scientific information possessed by Spanish surgeons was notably defective compared with the general level in Europe. Nevertheless, surgery was one of the branches of knowledge where doctors suffered the least by this lowering of standards. During this third of a century (1808-1834), in which the so-called 'fall' in the level of enlightened Spanish medicine occurred, Spanish surgical tradition was not on the whole interrupted, since it inherited, and to some extent, transmitted, the surgical knowledge which was so splendidly cultivated by the Royal Colleges of Surgeons of the eighteenth century. We refer to the work of Antonio San Germán, author of Tratado de afectos y Operaciones quirúrgicas, Leonardo Gali, Sebastian Aso y Travieso and José Rives y Mayor, professor at the Real Colegio of San Carlos. The work of San Germán, although drafted in 1805, was not published until 1821, during the 'Liberal triennium', which in itself indicates the difficulties under which these scholars had to work to avoid strict censorship.

During the years between the death of Ferdinand VII and the Revolution of 1868, knowledge of medicine and surgery shows a definite improvement over the very strict control of the previous period. During these years the scientific outlook slowly improved and it is of interest to note that Spanish surgeons of this period, as far as they could, studied the work of foreign surgeons, through a number of translations, especially the publications of Begin, Tavernier, Roche, Sanson y Vidal de Cassis, and especially the last-mentioned author. The surgical treatise by Malgaigne was also widely read. During this second period, surgery was enriched by a number of original contributions. López Piñero mentions that three circumstances contributed to the improvement of medical and surgical knowledge. ${ }^{172}$ First, there was the disap- 


\section{Juan Riera}

pearance of the absolutist regime. Second, there was the return of doctors from exile and better facilities for the publication of translated or original books. In addition there was a notable development of medical publications and journals. This helped to raise the scientific level of Spanish medicine during this transitional period. One of the characteristics of the more representative scientists of this period was that of working alone, for there were no true surgical centres until the following generation. The surgeons born between 1800 and 1815 are Joaquin Hysern y Molleras, Melchor Sánchez de Toca, Tomás Corral y Oña and, especially Diego de Argumosa y Obregón, who is without doubt the best representative of surgical knowledge and practice in Spain during the first half of the nineteenth century.

The reign of Isabel II (1833-68) represents a slow but effective improvement compared with the decline of scientific knowledge of the previous period; a recovery that we owe above all to the personal effort of a few surgeons. The ideological freedom resulting from the Revolution of 1868 increased this incipient improvement of favourable circumstances for the evolution of medicine. In addition we have the birth, around 1850, of quite a number of scholars whose research would begin to show itself during the second half of the nineteenth century. This generation, called the 'Generation of Scholars', had such important figures as Santiago Ramón y Cajal, the anthropologist Oloriz and the bacteriologists Jaime Ferrán and Ramón Turró, the physiologist Gómez Ocaña, and of course such surgeons as Salvador Cardenal (1852-1927), Eulogio Cervera (1855-1916), José Ribera y Sans (1852-1912) and Alejandro San Martín y Satrústegui (1847-1908), as we shall see later on. These surgeons were among those who fully accepted the antiseptic method of Lister, and introduced it to Spain. Two men who were of the greatest importance in the historical development of Spanish surgery were Juan Creus y Manso (1828-1898), and especially Federico Rubio y Gali (1827-1902). Both these surgeons, as we shall see further on, had an outstanding role in the introduction of antiseptics to Spain.

We should now examine to what extent the penetration of Listerism in Spain was favoured by the historical circumstances that affected Spanish medicine from 1850 . One of the factors that we must bear in mind is precisely the development in our country of the new bacteriological theories of Koch and Pasteur. The penetration of Listerism on the one hand, and bacteriological theories on the other, must have had inevitably many points of contact. We must accept as a premise that in order to favour Listerism, Spanish surgeons undoubtedly had to have a prior knowledge of the new bacteriological theories. The acceptance of micro-organisms as the causal agents of numerous pathological processes is an essential condition for accepting the theory of Lister. In fact the creators of bacteriology in Spain consist of three figures of prime importance. First we have Vincente Llorente Mateos (1857-1912), a founder of the microbiological institute of serotherapy. Of enormous importance are Jaime Ferrán y Clua, already mentioned, and Ramòn Turró y Darde, also a Catalan, who worked a great deal with the Institute of Hygiene in Barcelona. Besides this, we must bear in mind the notable recovery of Spanish surgery with the rise to fame of surgeons and the creation of new institutions, such as the centre set up by Federico Rubio, called the Instituto de Terapéutica Operatoria. A third factor favouring the acceptance of Listerism was the improved communication between Spain and Europe; 


\title{
The Dissemination of Lister's Teaching in Spain
}

this was partly due to purely political causes as well as to exclusively scientific objectives. Spanish surgeons were in frequent contact with European surgical centres. The two best examples are, perhaps, Federico Rubio and Salvador Cardenal, as we shall be able to show later.

\section{THE INTRODUCTION OF THE ANTISEPTIC SYSTEM TO SPAIN}

When was Lister's antiseptic method introduced to Spain? The high standard of Spanish surgery during the second half of the nineteenth century meant that, with due exceptions, the new Listerian theories were known very early on by Spanish surgeons although the speed with which these theories were accepted did not match that found elsewhere, especially in Germany. It should be said that although Listerism was widely known in Spain, there were many older surgeons who did not know that the new doctrines were derived from Lister.

First of all we would mention Diego de Argumosa y Obregón (1792-1865), Melchor Sánchez de Toca (1804-1880), Pedro González Velasco (1815-1882) and Rafael Martínez Molina (1816-1888), the four surgeons of greatest renown in Madrid in the middle of the nineteenth century. However, other personalities in Spanish surgery belonged to the pre-antiseptic era, such as Juan Ceballos (1818-1875) from Cádiz and Vicente Guarnerio y Gomez (1819-1880) who came from Granada. These were people of a certain renown, although not concerned with the problem that we are considering. Then later, within the following generation, we have Santiago González Encinas (1836-1887), Professor at the Faculty of Medicine in Madrid, who showed little concern with the antiseptic method. However, following 1870 a number of books were published such as that of Ramón Hernández Poggio, who wrote Tratamiento de las Heridas por Armas de Fuego (Madrid, 1872), a work which spoke of the use of carbolic acid, although not mentioning the work of Lister; it would appear that he used carbolic acid since he states

\begin{abstract}
phenic acid or carbolic acid which comes from the mineral pitch, produces surprising effects in the treatment of this infirmity, and used in due proportion diminishes suppuration and accelerates healing of the wound or ulcer. When, because of the effect of humidity, this acid liquefies and appears as a liquid of reddish colour, I use it according to the following formula, which was used in Seville in 1868, although varying the quantity of carbolic acid according to the indications of the wound. (p. 187).
\end{abstract}

This usage appears to be only an empirical one, without any theoretical basis, and for this reason we include him in the pre-Lister generation. However, in 1881, in a brief publication, dealing with the lessons on antiseptic surgery given by the English military surgeon Longmore, Poggio violently attacked the Listerian theory, denying the harmful consequence of wound suppuration. ${ }^{146}$ Another Spanish surgeon who might well belong to the legion of Listerian surgeons who left the pre-Lister generation is Salvador Badía.* This author, in his Cartas médico-quirúrgicas Escritas sobre el Terreno con Motivo de la Guerra Franco-Prusiana de 1870-71 (Barcelona, 1872), was concerned with Listerism as a method of treating wounds, including notes on statistics, etc., although without conceding to this discovery the importance that it really should have had; according to this Spanish surgeon, Lister's method was only one

* See A. Elias de Molins (88), I, 186-7, and A. Pulido (224), 249 
among many others tried in the treatment of wounds. Also the work Tratado de Patologia quirúrgica general (Madrid, 1876) by the Professor of the Faculty of Medicine in Madrid, Adolfo Moreno Pozo,* belongs fully to the pre-antiseptic period of surgery, as also does the Tratado de Patologia quirúrgica general (Valladolid, 1878, 2 vols.) by the Dean of this faculty, Nicolás de la Fuente Arrimadas. ${ }^{140}$ Here there is no mention of the microbial aetiology of suppuration, and the author refers vaguely to ferments and microphytes which exist in the air. At the end of this book there is a concise history of surgery without any mention of the decisive discoveries of Lister in the field of antiseptic surgery. Somewhat later, and still opposed to Listerian theory, is the writing of Nicolás Rodriguez Abaytúa, entitled Inaplicación terapéutica de la Antisepsia interna (Madrid, 1888), a work which is a thorough attack on the fundamental of bacteriological theory.

Then we have the work Clinica quirúrgica (Madrid, 1891) by Lucio López Arrojo; and to this list we can add the names of Gomez Pamo Ferradas, Florencio Castro, Pérez Obon, and José Rodríguez Benavides, who all belong to the pre-Listerian era in Spanish surgery. Cortejarena y Aldebó (1835-1919) was also opposed to Listerism, and he often mentioned his 'tissue paper treatment' as opposed to the antiseptic method of Lister.

TRANSLATIONS AND PUBLICATIONS ON THIS SUBJECT

Separate mention should be made of the publications and translations on Listerian surgery printed in Spain.

The interest of Spanish surgeons in these problems was aroused by the publication of translations of the works of such important writers as Nussbaum. His Lecciones de Clinica quirürgica (Madrid, n.d.) and especially his Cura antiséptica expuesta según el Método de Lister (Seville, 1880) were significant; the translations from the German were by Emilio Reina Martín and Gonzalo Angulo Laguna.

The Spanish versions of the publications of Lucas Championnière, the greatest defender of Lister in France, were of tremendous importance. His Cirugia antiseptica (Madrid, 1877) was translated by Vélez y Martínez. Some years later there appeared a version by Jenaro Lacalle of Cirugía antiséptica y Aplicación del Método de Lister. However, we possess only partial translations in Spanish of writings and lectures by Lister. ${ }^{168-9}$ With regard to Spanish surgery it is worth mentioning Lister's lecture to the Medical Society of London on 4 November 1889, in which he referred to Spanish surgeons as follows: 'This gauze [serum sublimate gauze] gave very satisfactory results, not only in my hands, but also in the hands of surgeons in such distant places as Bologna and Spain.'167 In fact, two outstanding Spanish surgeons had personal contact with Lister. These were Salvador Cardenal y Fernández, and Alejandro San Martín y Satrústegui. Also, the editor Antonio Espina y Capo visited Lord Lister at his London clinic.

In addition to these translations of undoubted interest to Spanish surgeons, there were other publications on the same subject. Taken altogether, these show clearly the marked Listerian trend that occurred in Spain. First, because of its importance, we should mention the work of Salvador Cardenal y Fernández; Guia práctico para

* See J. Alvarez-Sierra (18), XIV, 6, 200, and A. Pulido (224), 368. 


\section{The Dissemination of Lister's Teaching in Spain}

la Cura de las Heridas y la aplicación del Método antiséptico en Cirugia (Barcelona, 1879).45 This was later amplified in a second and third edition, published in 1887 and 1894, under the title of Manual práctico de Cirugia antisépitca, undoubtedly the best Spanish contribution to Listerism.

Although monographic in character, the work of Enrique Areilza y Arregui* should be mentioned as outstanding: Valor de la Cura de Lister en las Heridas contusas (Madrid thesis, 1880). Juan Aguilar y Lara, ${ }^{* *}$ from Valencia, published a book on the same subject entitled Lister y Guérin. La nueva Cirugía antiséptica. Historia, principios, manual operatorio y resultados (Valencia, 1882). Two years later Lorenzo Aicart y López wrote La Cirugia antiséptica (Madrid, 1884). Leopoldo Cea wrote on Apósitos y Vendajes antisépticos (Valladolid, 1888). Two publications we have not been able to consult we also believe to be of interest: La Cirugía antiséptica (Madrid, 1888) by Enrique Mateo Barcones, and Prontuario de Cirugía asepto-antiséptica. La Cirugia moderna, sus principios, procedimientos y resultados (Pamplona, 1890) by Jimeno Egúrvide. Cura antiséptica (Madrid, 1890) is the title of a work by De Vicente Miranda Bistuer, while Algodones y Gasas medicinales empeados en la Cura antiséptica (Barcelona, 1890) is by M. Fernández Casadevante. Judging by their titles, these works appear to be of interest. Finally, and going outside the strict limits of the nineteenth century, we would mention the work of Jerónimo Pérez Ortiz*** entitled Memorias de Cirugia. Personalidades quirúrgicas en Francia y Suiza. Concepto actual del cirujano, asepsia y antisépsia (Madrid, 1904).

\section{THE THEORY OF LISTER AT MEDICAL CONGRESSES}

A good indication of the degree of acceptance of the new antiseptic theories within the general framework of Listerism in Spain is provided by the medical congresses. In the last three decades of the nineteenth century, the Congresses of Cadiz, Seville, Madrid and Barcelona provide good evidence of the interest among Spanish surgeons in the theories of Lister. At the Regional Congress of Medical Sciences at Cadiz (1879), ${ }^{68,7}$ supporters of Lister were, among others, Enrique Moresco y Labade, of Cadiz, Federico Rubio, Hontañón, Antonio Gómez Torres, the latter Professor of Obstetrics and Gynaecology at Cadiz and later at Madrid, and finally two surgeons, of whom the name of only one is known, Izquierdo y Alcina. Among them, Gómez Torres acepted the Verneuil procedure and Diaz Rocafull followed the alcohol treatment regime; Cabello and Perales adopted a negative attitude to Lister. In 1882, a year later, the International Medical Congress was held in Seville. ${ }^{65}$ There Dr. Chiralt spoke on the antiseptic method as applied to the battlefield.

The Congress of Medical Sciences of Barcelona, 1888,22,68 is of greater interest in relation to the dissemination of Lister's methods in Spain. At this scientific meeting nearly all those present, without exception, were in favour of Lister's ideas. Among others, we would mention the names of: Salvador Cardenal, Antonio Espina y Capo, José Coll y Morros, Alejandro San Martín, Alvaro Esquerdo, Miguel Fargas, Juan Manuel Mariani y Larrion and, in addition, the names of Rafael Rodríguez Méndez, Valle (Madrid), Sojo Batute y Hernández Formiguera and Felipe Margarit y Cervera

* See Luis S. Granjel (140).

* See A. Pulido (224), 229-31.

*** See J. Perez Ortiz (218), Introd., xi-xxxv; Pt. I, Sec I, Cap. 1, 3-21. 


\section{Juan Riera}

(Madrid). One of the official subjects of this congress was 'Antisepsis in general. How do antiseptics work?' This shows the increasing interest in the Listerian method in Spain. On this subject we shall include the contribution of two surgeons, Población and Castells, both supporters of antisepsis for surgical lesions caused by firearms.

There follows the Hispano-Portuguese Congress of Surgery held in Madrid in April $1898 .^{2}$ The significance of this, in relation to antisepsis, lies in the general acceptance of Listerian ideas by the participants in this scientific meeting. However, some centres of surgery still held on to the old ideas; this is confirmed by the words of Manuel González Tárrago y Garcia at this Congress, 'There are some Spanish surgeons however, who deny the efficacy of asepsis in surgery; there are some surgeons to whom asepsis is no more than a new craze, a fashion with which modern surgeons pretend to get results they were already getting with the old methods, and which they continue to get in their hospitals with Listerian treatment.' ${ }^{134}$ It would seem, when one weighs these words, that notwithstanding the introduction of antisepsis and the later improvements of the 'aseptic method' of Bergmann, there were quite a few clinicians who opposed this important scientific innovation.

MEDICAL LITERATURE: THE DISSEMINATION OF LISTER'S METHOD IN SPAIN

Before surveying the main surgical centres that early-on adopted Lister's method, we should include a brief mention of the part played by editors of the more important journals in disseminating the antiseptic method. They generally published short notes, reviews, etc. Despite the fact that these are of very secondary importance they must nevertheless be considered. Often they appear without the author's name. When they do, they are often not in the names of surgeons. Rather than compile an exhaustive list, we have considered it better to refer only to those reviews that appeared in some of the more important and more widely circulated journals, written by some of the better known contributors to Spanish medical journals of the nineteenth century. Four authors are sufficiently representative to be cited. Antonio Espina y Capo* (1850-1930), from Ocaña, was Professor at the Hospital General and also a member of the Royal Academy of Medicine and the Medical Surgeons' Society. Although not in practice as a surgeon, he published, at a relatively early age (1878), journal notes wherein he clearly accepted the antiseptic treatment of Lister. He was also one of the few Spaniards who had personal contact with Lister, as is confirmed by the following: "this was the true impression we received from our all too short conversation with Dr. Lister'.** His contributions were published in the Revista de Medicina y Cirugía prácticas.

Ramón Serret y Comím,*** from Valencia, editor of $E l$ Siglo Médico already mentioned our subject in 1874, and continued this in a series of reviews all directly linked with problems of Listerism, which was highly praised. Notes were also published by Juan Manuel Mariani y Larrión (1853-1909) and by Federico Toledo, both editors of the Revista de Medicina y Cirugía prácticas.

THE INFLUENCE OF ANTISEPSIS ON THE DEVELOPMENT OF SURGICAL SPECIALITIES

Although, of course, this particular aspect goes beyond the limits of our survey,

* See Luis S. Granjel (139), 311-323.

* See A. Espina (169), IV, 266-7.

*** See A. Pulido (224), 413-4. 


\section{The Dissemination of Lister's Teaching in Spain}

a very brief summary needs to be given here. It is worthwhile picking out the rapid acceptance that Listerian theory obtained among some Spanish specialists: especially ophthalmologists, gynaecologists and neurosurgeons. In gynaecology, it is sufficient to mention the names of Miguel Fargas y Roca, Eulogio Cervera and Francisco Campá, who at a very early date, as we shall note further on, used antiseptic methods in their gynaecological interventions, especially ovariotomies. This type of intervention, one of the earliest carried out in Spain adopting Listerian precepts, shows how the work of Lister had become accepted in Spain not only in relation to general surgery but also in the case of surgical specialities.

Very similar also is the case of surgical ophthalmology. A whole cluster of Spanish eye-surgeons of the first rank were supporters of the Lister system. It is sufficient to cite, as an example, the attitude of such specialists at the Congress of Medical Sciences at Barcelona in $1888 ; 320$ Barraquer, Chiralt, Menacho, etc., defended the application of the ideas of Lister to eye operations.

In regard to neurosurgery, ${ }^{*}$ there is no doubt that the development of this speciality was caused, among other things, by the new techniques of antisepsis and surgical asepsis. So much so that in considering the historical perspective of this speciality in Spain we must note this clear-cut separation of the last three decades of the nineteenth century. The more important neurosurgeons of this period were: Enrique Areilza y Arregui, Eulogio Cervera, etc.

\section{THE SURGICAL CENTRES OF MADRID}

Among those bodies concerned with the introduction of Lister's method to Spain, the surgical centres of Madrid at a very early date employed the materials and ideas proposed by Lister in his antiseptic treatment. There are a number of such centres to be listed; first of all there is the Faculty of Medicine, and the Institute of Operative Treatment, followed by the Princess Hospital, the Military Hospital of Carabanchel, and finally, the General Hospital. However, there is no clearcut distinction and a completely isolated consideration of these centres is perfectly valid. Also the idea of antisepsis was debated in the societies and academies of Madrid quite frequently and these found their defenders and detractors and we shall, later, concern ourselves with all these matters.

\section{(a) The Faculty of Medicine}

The Faculty of Medicine of Madrid had some outstanding personalities during the second half of the nineteenth century. These are, first, Juan Creus y Manso ${ }^{154,312}$ (1828-1897), José Ribera y Sans (1852-1912) and, of less importance, José Calvo y Martín (1815-1904), Santiago González Encinas (born 1836), except, however, for Alejandro San Martín y Satrústegui (1847-1908); the participation of these surgeons, as we shall see, was unequal in regard to the process of introducing the antiseptic method to Spain. Outstanding among these is Creus y Manso. This surgeon was born in Guadalajara, and he held the Chair of Anatomy and Surgical Pathology in Granada from 1854 to 1877, and then moved to Madrid until he retired. The figure of Creus y Manso is possibly one of the most important in the panorama of Spanish surgery in the nineteenth century. Also in relation to the introduction of Listerism to Spain,

* See J. Lopez Pinero (173). 


\section{Juan Riera}

his participation is very important. We know that during 1873 and 1874 he used prepared catgut as ligature material. He was decidedly in favour of Lister's method, as reported by Garcia Solá, who quoted Creus: 'The biggest step in surgery is owed to the theory of microbes. Only Edward Jenner may be compared to Lister in regard to the effective benefits given to humanity."* During the academic year 1873-74, Creus practised antisepsis in the treatment of wounds, and hence the Faculty of Medicine of Granada was one of the first centres to use the antiseptic method.

However, we believe that Creus y Manso became completely attached to Madrid University, as shown by the list of pupils taught by him. There were for instance, Luis Guedea y Calvo (born 1860), who later held the Chair of Surgery at Cadiz, Antonio Morales Pérez (1858-1918), who held a Chair at the Faculty of Medicine of Barcelona, José Ribera y Sans (1852-1912), José Ortiz de la Torre (1858-1928), Enrique Isla Bolumburu (1854-1929). There is no doubt that this generation of surgeons was taught directly by Creus and, necessarily, he taught the Listerian method, among other things. During the course of his teaching at Madrid in 1877-78, he regularly used antisepsis. This is shown in the clinical histories published by his pupils, Manuel Tapia y Serrano, Félix Creus, José Grinda and Juan de Azúa. Creus carried out an amputation in 1878 and he used the various materials recommended by Lister: carbolic solutions, Championnière sprays, the protector and the macintosh, antiseptic gauze and bandages, together with drainage tubes. Similarly in some of his surgical publications he praises the methods of Lister; we also have interventions by Creus at the Royal Academy of Medicine, defending Lister's method. Creus is possibly one of the first Spanish surgeons, if not the first, apart from Rubio, who introduced antisepsis into his surgical procedure.

One of the most important Spanish surgeons of the nineteenth century, a disciple of Creus, and one who therefore continued his work, is José Ribera y Sans, ${ }^{* *}$ who heads a numerous group of excellent surgeons. Ribera accepted surgical antisepsis; however, his enthusiasm was not very great, if we judge by his words: 'I must confess that which I already stated, in commenting on the results obtained during the course 1889-1890: it is not possible to consider surgical antisepsis in the Faculty of Medicine in Madrid and we can only have a relative antisepsis. ${ }^{* * *}$

These textual statements by Ribera are in contrast with the publications of this author, which would only make us suppose that material shortcomings made it impossible to convert antisepsis into a reality. Much less convincing is the work of the other holder of the Chair of the Madrid Faculty of Medicine in the diffusion of Listerism in Spain; José Calvo y Martin, already referred to, ${ }^{41}$ mentions this in a few words given at the Royal Academy, which made him President; his best defence of Lister's method is in the discourse read to the Academy on the theme of: La cura de las heridas, 1881, where he recommends the usefulness of Lister's methods.

Santiago Encinas, $f$ also holder of a Chair in Madrid University, refers to Lister's treatment in the surgical treatise Metodologia y Principios generales de Clínica Quiruirgica, 1883. In this work he mentions the antiseptic treatment without much

\footnotetext{
* See E. García Solá (154), 135-140.

* See A. Pego Busto (216).

*** See J. Ribera y Sans (235).

† See M. G. Garcia del Carizo (122).
} 


\section{The Dissemination of Lister's Teaching in Spain}

enthusiasm, and he refers to the causes that prevent its general use and modifications and improvements of it, as well as methods of making it cheaper. He devotes an entire lesson to these problems, ${ }^{*}$ giving facts concerning the cleanliness of drainage tubes, simple treatment, etc. His ideas could not be called those of orthodox Listerism, and it is sufficient to quote as follows: 'The antiseptic treatment of Lister is above all a protective treatment, and it is only secondarily concerned with antisepsis, and in any case, there is no certain proof of it."**

Of greater scientific importance is the figure of Alejandro San Martin, $\uparrow$ undoubtedly one of the great Spanish surgeons of the second half of the nineteenth century. He studied in Madrid with the bacteriologist Mendoza, and is one of the very few Spanish surgeons, as we have already mentioned, who personally knew Lord Lister. His contact with European surgical centres was not infrequent, and we would mention his visits to surgical clinics of some European cities, among them Edinburgh, London and German centres, the clinics of Bergmann, Mickulicz, Küster, etc. At the SpanishPortuguese Congress of Surgery (1898), San Martin was one of the surgeons who defended the ideals of Lister.

\section{(b) The Rubio Institute}

As we have already mentioned, the creation of this new surgical centre was of decisive importance in the further development of surgery in Spain. Its role in the introduction of antisepsis in Spain, we believe is also of some value.

It was founded by Federico Rubio y Gall (1827-1904), $\mathrm{ft}$ who is without doubt the most important figure in Spanish surgery in the second half of the nineteenth century. He was, for instance, the first person in Spain to employ systematically ether and chloroform; his life is an example of beneficial contact with Europe, both for political and scientific ideas, and, in fact, he is one of the surgeons who established the greatest communication between Spanish and European surgery. It is not strange, therefore, that he is one of the first surgeons in Spain who showed an interest in the theories of Lister. In fact, the first known work of this surgeon from Cadiz is concerned with the problems we are considering. It was published in 1872. Also we should note that Federico Rubio was not too faithful to the more orthodox postulates of Lister since he introduced some changes, for example, the substitution for carbolic acid, recommended by Lister, by alcoholic applications. He took part quite frequently in congresses and scientific meetings and he showed quite clearly that he was a proponent of antisepsis. This may be seen by his contributions to the congresses of Cadiz (1879) and of Barcelona (1888). The following quotation is fairly explicit:

We must say a few words on treatment. It would be tiresome to discuss the principles on which antiseptic treatment is founded; we assume that our readers are informed on the matter. We would merely refer to the advantages and inconveniences that we have encountered. It would not be correct if we stated that we are satisfied by it. Even supposing the action of carbolic acid to be non-existent in preventing putrefaction and fermentation and without conceding any advantages other than scrupulous cleanliness and the avoidance of pestiferous unguents, that

* See S. Encinas (89), Lec. XIVIII, $652 \mathrm{ff}$.

** Ibid., 637.

t For the life and work of this surgeon see 17, 135, 190, and 322 .

Ht There is still no definitive biography of Rubio, but accounts of his life and work are to be found in $16,32,126,142,174,180,251$, and 259. 


\section{Juan Riera}

is enough for us to prefer this treatment to the usual kind. We have used antiseptic treatment in the majority of cases; we are satisfied with it and we shall continue to use it.*

However, in 1881, the date on which these words were published, the interpretation of Lister's thinking by Federico Rubio was not entirely adequate; he was one of the first Spanish surgeons to issue the news of this development, nevertheless his acceptance does not lead to enthusiasm regarding the use of it in all surgical interventions. By the side of Federico Rubio there stood a good number of Spanish surgeons, some of first rank who necessarily came into contact with Listerian surgery in this centre. Among the many disciples of Rubio we would only mention three enthusiastic proponents of antisepsis: Eulogio Cervera (1855-1916), Antonio Martinez Angel (1845-1931), and Eugenio Gutierrez (1851-1914), especially the last two, who from 1886 made a definite contribution to the perfection of the art of surgery. As with Federico Rubio, some of these surgeons travelled to a number of European centres. Such is the case of Martinez who was an assistant to Volkmann, and afterwards a successor to Rubio as head of the Instituto de Terapéutica Operatoria.

\section{(c) The Military Hospital of Carabanchel}

It is not surprising that antiseptic surgery should find supporters among military surgeons. Here we have one of the centres of Madrid with figures of the first rank on this subject, namely, Jerónimo Pérez Ortiz and Lorenzo Aicart López, the most outstanding surgeons of the military hospital of Carabanchel. We do not know very much about the former, although his writing on Cirugia de Urgencia (1895) contains a fair amount of material on the theories of Lister.** Both in the introduction and the section on the treatment of wounds, we find Lister's ideas outlined, Nevertheless, and with some priority, in his dermatological work, Pérez Ortiz used Listerian prescriptions in the treatment of some skin diseases. Of greater interest, although belonging to the twentieth century and not really our concern here, is his work Memorias de Cirugia (1904) in which the concepts of asepsis and antisepsis are referred to at length.

Lorenzo Aicart y López of the Medical Corps, published in Madrid in 1884 a work dedicated entirely to the problems of antisepsis. His Cirugia antiséptica is in fact the result of a report he submitted to the Academy of Medicine in Andalucia concerning these matters. In this communication Aicart tried to throw light on the most suitable treatment to be used in military surgical centres, and he takes into account various factors, efficacy, how to obtain it, its cost and ease of transport. We may observe, it is not only a scientific study of Listerism, but also a survey of the possibilities of adaptation of military resources. In his work he is also concerned with the concept of antiseptic surgery, following the origin and method advocated by Lister. A number of antiseptic substances, especially the more important ones, are given comparative study, and he also provides information on how dressings are made up. In concluding this report Aicart describes the dressing of Guérin; and it seems that he follows in some points Vincent von Kern's ideas on the treatment of wounds. Among the more important conclusions of this author there are, however, some of the primitive ideas on the subject of 'fermentation', although he undoubtedly prefers the Lister method.

* See F. Rubio (247), 101.

** See J. Perez Ortiz (218), Introd., xi-xxxv; Pt. I, Sec. I, Cap. I, 3-21. 


\section{The Dissemination of Lister's Teaching in Spain}

Also the materials used are generally those advocated by Lister. Only when deficiencies of a material order make it impossible to put Lister's treatment into practice does Aicart accept the possibility of substituting it by alcoholic treatment. He does follow, however, the general precepts for Listerian treatment.

\section{(d) The Princess Hospital}

Antiseptic surgery was to be found in the Princess Hospital before 1880. Among the surgeons who worked here during these years were Morales, Berrueco and Cospedal. Morales was a pupil of Creus and some years later holder of the Chair of the Faculty of Medicine in Barcelona. In addition to Morales, we may say that three surgeons of great professional prestige worked during these years making use of the new Listerian treatment: (1) Joaquín Berrueco y Sanchez (1855-1923), * who eventually became Dean of the Hospitals for the Poor in Spain; and (2) Antonio Cospedal y Tomé (1855-1942).** who for some time worked with Creus, and from 1884 was at the Princess Hospital. However, his work was basically gynaecological. At the same centre was (3) José Ustariz y Escribano (1848-1903), ${ }^{* * *}$ from 1901 a member of the Royal Academy. Of all the surgeons in this hospital, he was most in favour of Lister's method. His early work on cotton-wool dressings (1876) clearly shows his acceptance of the theories of Lister. For him, unlike the statements of Guérin, cotton-wool dressings are not sufficient to keep a wound aseptic. Much more is required; it is necessary to use chemical substances like carbolic acid. On other occasions (1879) he recommended the antiseptic thymol in a comminuted fracture of the upper third of a tibia and the right fibula, outlining the development of this case. As a member of the Medical and Surgical Academy of Madrid, he spoke in 1885 on the subject of 'Antisépsia e Higiene de los Hospitales', outlining a number of considerations on the application of Lister's theory. Before 1880 Carlos Ma. Cortezo y Prieto practised antiseptic surgery in the hospital during his younger days.

\section{(e) The General Hospital}

The involvement of the General Hospital in the diffusion of the antiseptic method in Spain is of less importance. We have found two contradictory opinions expressed, that of Victor Escribanot on the one hand, and that of Antonio Espina y Capot† on the other. Victor Escribano belonged to the surgical school of Creus and he overvalued the contributions of this surgeon and minimized the involvement of the General Hospital in the introduction of Lister's ideas to Spain. Espina y Capo on the other hand believed that this centre was one of the first to accept antiseptic standards. We ourselves have not been able to come to any firm conclusion. It appears that the affirmation of Escribano refers to the period prior to 1880, while Espina y Capo is concerned with the decade between 1880 and 1890 . This is the only way of reconciling both attitudes. According to the ideas of Escribano, except for Enrique Isla Bolumburu (1854-1929), $+\dagger \dagger$ who was an excellent surgeon, no leading surgeon was

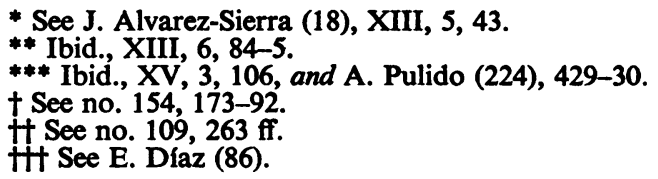




\section{Juan Riera}

concerned with up-to-date practices, neither Pérez Obón, nor Marceliano Gómez Pamo (1890), both from the generation born around 1830, nor J. R. Benavides y Aguinga, although Espina y Capo, talking about Benavides states: 'Our surgeon Benavides was a forerunner in using carbolic acid at the General Hospital for the treatment of wounds."*

Also according to this author, the use of antisepsis in very early days was adopted at the General Hospital: 'In Spain, the surgeons of the Hospital, there was Gómez Pamo y Lanzagorta, and in the Faculty of Medicine, we would add with less enthusiasm Encinas y Creus.'**

The decade of 1880-90 for Espina y Capo is the golden age of the method of Lister and he is enthusiastic in remembering Spanish surgeons of the General Hospital who used Lister's method, who were immersed in the atmosphere of sprays. It was always, according to Espina, at the General Hospital that these developments were first accepted.

\section{SOCIETIES AND SCIENTIFIC ACADEMIES}

Besides those surgical centres where the actual application of the new antiseptic treatment was taking place, the Listerian system was the subject of polemical discussions in the strictly academic field where supporters of these new ideas confronted each other and where they opposed those holding on to the traditional practices of the pre-Listerian era. There were two national centres in Madrid where these problems were discussed, the Royal Academy of Medicine and the Medical and Surgical Society of Madrid.

The Royal Academy of Medicine had numerous sessions dedicated to the discussion of these problems. During 1880 and 1881 sessions took place in which different members proclaimed themselves supporters or opponents of the Listerian system. This extended argument needs to be gone into in greater detail.

One would not say that the Royal Academy was a fervently Listerian centre, although there were always defenders of the system. However, the words we quote from Antonio Morales Pérez are not without justification: 'Without going outside Spain, in the Academy of Medicine, the question of antiseptic treatment has been received by the majority with little confidence.'***

In the various academic sessions ${ }^{288-302}$ supporters of the Listerian treatment, among others, were Lacasa of the General Hospital, the first, possibly, to carry out this treatment in this centre, Federico Rubio, Juan Creus y Manso, Isidoro Miguel y Viguri, to which we could add the names of Ustariz y Escribano, Calvo, Ribera y Sans, Alonso and Adradas.

Always discussions took place in the presence of the great enemy of the Listerian system, Dr. Francisco de Cortejarena y Aldebó (1835-1919), † who with monotonous insistence advocated his 'tissue paper treatment', a deformed and later variant of the non-aseptic occlusive treatments with cotton-wool put forward by Guérin. This surgeon pretended to preserve wounds from infections by means of an occlusion with

* See A. Espina (109), 263.

** Ibid., 267.

*** See A. Morales (199)

† See A. Pulido (226). 


\section{The Dissemination of Lister's Teaching in Spain}

tissue-paper, and he believed that he obtained better results than with the antiseptic treatment of Lister. His statements were quite strange inasmuch as not only did he deny the Listerian system but even bacteriology itself, and he is only mentioned for comparative purposes as a sample of one of the most bitter enemies of the Listerian doctrine in Spain. However, this attitude did not become generalized and other surgeons quite adequately opposed the inventor of tissue-paper treatment. The figures presented to the Royal Academy by José Ribera y Sans ${ }^{301}$ concerning six hundred and forty-five operations carried out with the antiseptic method are of great importance: in this series only forty-two people died.

Some opposition to Lister was to be found in the Medical and Surgical Academy and we quote the opinion of Lacasa: 'I understand that Espina is introducing the method of Lister to our country (1882), according to a discourse that he pronounced at the Academy of Medicine and Surgery. Quite unreasonably his words were received sceptically since we are dealing with new ideas. I felt the desire to try out this new treatment, which would satisfy some of the doubts which have arisen.191

In this Academy some other surgeons were also favourable to Listerism: Isidoro Miguel y Viguri and José Ustariz y Escribano.

\section{SURGICAL CENTRES OF BARCELONA}

In dealing with the introduction of Listerism to Catalonia, we must limit ourselves to the surgical centres of Barcelona, owing to their greater importance. We must, however, deal first of all with the work of Salvador Cardenal, because of his extraordinary importance in the spread of Listerian theories in Spain.

\section{The work of Salvador Cardenal Fernandez}

Two stages may be perceived in the scientific life of Salvador Cardenal:* the preand post-Listerian period of his professional activity. From 1878 he was a definite supporter of the Listerian system and he consecrated a great part of his scientific activity to its dissemination up to the point of being its champion in Spain. If we were to reduce to one word the central nucleus of this surgeon's work, both as a surgeon and a publicist, we should use the term 'Listerism', since this is the actual theory which is to be found throughout the writings of Cardenal. His theoretical affiliation is quite evident; his attitude is not limited, as in other cases, to adopting a series of surgical means in order to reach more favourable results; he had to adopt the method of Lister as a system. He used alcohol empirically as an antiseptic means and from 1878 he defended these new ideas systematically. The scientific work of this surgeon is on an ascending scale, each time more complete, from his first work Guia práctico para la Cura de las Heridas, 1879, amplified and improved with later editions in 1887 and issued in 1894 under the title of Manual práctico de Cirugia antiséptica. However, we must also report his contributions to medical journals and his contributions to the congresses of medical sciences of Barcelona (1888) and Madrid (1889), the latter being of fundamental importance. We must mention his interventions in favour of Listerism at the Royal Academy of Barcelona. His contacts with the major European surgeons should be noted and in 1875 he began a series

* There are many biographical studies of Cardenal, but none is definitive. See refs. 13, 56, 63, 69, $121,201,205,217,260,313$. 


\title{
Juan Riera
}

of journeys to Paris and then visited the surgical clinics of Billroth, Volkmann, Esmarch, Pean, etc. On other occasions he visited London and especially Lister, on two occasions, in 1883 and 1890 , and Cardenal is quoted as saying:

\begin{abstract}
After having made some trials on this matter and trying to obtain the same results as the English professor, I wrote to Lister, asking him if it might not be dangerous to interfere in a given case unknowingly, using the serum of some horse who was ill with a zymotic affection; whereupon the esteemed professor of King's College replied that he had been able to prove to himself directly that the addition of sublimate to serum, for some hours and in the cited proportion of one per thousand would completely prevent the activity of any kind of disease-causing agent.*
\end{abstract}

On other occasions Cardenal mentions his visit to the surgical clinic of Lister: 'I cannot forget the wounds seen by myself in 1883 in Lister's surgery, using his antiseptic device; they showed an incomparably more normal aspect than in 1890 I was able to observe in one of the masters of modern asepsis.'**

On another occasion he states: 'A detail which was drawn to my attention during my assistance at the clinic of Lister in King's College Hospital, is that this gentleman, in talking of antiseptic practices, never referred to "my method", but always to "the antiseptic method".***

What is the role played by Cardenal in the introduction of antiseptics to Spain? We find the answer given by one of the most notable Spanish surgeons of the second half of the nineteenth century, Alejandro San Martín, who states:

Dr. Cardenal is one of those surgeons who has laboured the most to elevate Spanish surgery to the level of other nations and without discussing whether he should be given the priority for having introduced antiseptic surgery into Spain, for the simple reason that there are at least half a dozen surgeons who would take on themselves this kind of priority, I must admit that amongst us he has been one of the most tireless propagandists of the method and I would say that Cardenal has done as much for Spain as Lucas Championnière in France. $f$

It is impossible to mention in this brief note the depth of the scientific work of Cardenal, and we would refer to only two aspects, since a detailed exposition would not be possible. First of all we would mention the defence of Lister when confronted with Lawson Tait, and secondly we would refer to the statistics of operations which were carried out with the antiseptic method. However, in presenting these aspects, of which we give details further on, we would mention the influence of Jaime Ferrán on the work of Cardenal. In his first writings and in those appearing later, there is a notable difference, explicable in part by his travels and contacts with European surgery. However, there are elements of the bacteriological thinking of Ferrán in the major writings of Cardenal on the antiseptic method. As if it were a case of parallelism, the influence of Pasteur on Lister is repeated in the case of Ferrán with Cardenal. In both circumstances the creation of a bacteriological 'climate' is essential prior to the diffusion of antisepsis. The case of Cardenal which we are studying is quite significant since his major surgical writing, the already-mentioned manual (1894) concludes with an ample appendixt† written jointly by Cardenal and Ferrán

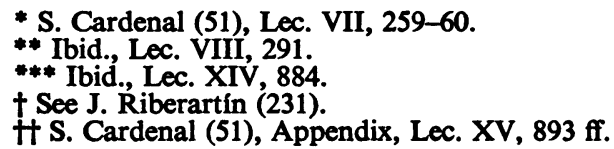




\section{The Dissemination of Lister's Teaching in Spain}

with a good part of the annotations by the famous Catalan bacteriologist. In this appendix and under the title of De Bacteriologia quirurgica, they outline various problems.

Of singular interest is the defence that Cardenal makes of the work of Lister. Confronted with Lawson Tait he stated:

It must be confessed that if the writings of Lawson Tait on this subject are read carefully, one finds a sectarian spirit, and a virulence and antagonism to Lister that is of a personal nature. It lacks the serene and impartial approach of a man of science who is trying to discover the truth. The last discourse to which I refer, pronounced in England on returning from the Congress of Berlin, in an invective full of bitterness and passionately against the elevation of Lister to his pre-eminent position and for which he was respected by all those who practised surgery; further we find here many errors of understanding of Lister's ideas and his school; personal attacks against the master are frequent and the whole discourse is full of an aggressive spirit, not very cultivated, not pertinent in scientific discussions.*

Cardenal shows no less energy in replying to the sectarianism of Guérin as follows:

One of the main subjects of discussion for Guérin is the question of the foetor of his bandages, at the moment of removing the dressing. He confesses that the dressing removed in the presence of the Commission of the Royal Academy of Sciences, who were drawing up a report, gave out a repugnant odour, and the hand of the patient covered by the dressing was bathed in a black and foetid pus; he attributed these facts, which unfavourably impressed the members of this Commission (Messrs. Grosselin, Larrey and Pasteur), to not having washed and disinfected the limb and to the bandage having been applied, not by himself, but by a pupil who was not very experienced. But I have to add this fact that during the time that I was at the Clinic of Guérin [in 1875], I saw myself a repetition of this phenomenon, so strange according to Guérin, and I was able to convince myself that the so-called traumatic fever was not only constant but also sometimes very high as a result of the cotton wool dressing applied by the very inventor of this method. The matter boils down to the fact that Guérin tries to establish a comparison between his cotton wool dressing and the method of Lister, and this comparison is not possible for a very simple and clear reason; the invention of Guérin constitutes a mode of healing or a system of dressings, a bandage for wounds, whilst the invention of Lister is a method of treatment, a special system not only for dressing or curing a wound, but also a mode of dealing with the wound aseptically if the result of an operation, or of arranging it, altering it, modifying it, draining it, and getting it into similar conditions (compared with subcutaneous tissue) if the wound is traumatic. The healing material (gauze) was only a detail of the method of Lister. The truth of these facts became imposed so profoundly on Guérin himself that in describing the technique of his dressing he included, as an integral part of its application, the disinfection of the wound with a strong solution of carbolic acid, disinfection of all surrounding parts, and the use of aseptic and absorbable materials such as the catgut of Lister, etc. That is to say that, sometimes without being aware of it, he accepts the fundamental principles of the new aseptic surgery, so much so that he did not say anything when I was present in the above-mentioned circumstances, nor did he mention anything in his work with his pupils. We must state without ambiguity, that before the spread of Lister's method, neither in Spain nor in France was any kind of antiseptic precaution taken in the treatment of wounds; suppuration in wounds was a classic fact, even in the clinics of Grosselin, Richet, Péan, etc., as well as in those of Guérin, and to pretend to make a wound already infected aseptic merely by using cotton wool is simply a scientific aberration. Guérin states everywhere that it has been demonstrated that cotton wool holds atmospheric germs by filtering them. No one doubts this, but it does not kill and it does not cancel out those germs that are on the wound and nearby and its use is insufficient without association of every means of antiseptic surgery. The cotton wool dressing of Guérin is, of course, an excellent dressing and a very useful protective means of compressing and keeping wounds dry and to have done this makes our author worthy of every consideration and respect; but is it NOT a specific and much less an antiseptic method of treatment in itself.**

$$
\begin{aligned}
& \text { * Ibid., Lec. IV, } 199 \\
& \text { ** S. Cardenal (51), Lec. XIV, 874-5. }
\end{aligned}
$$




\section{Juan Riera}

The statistics of surgical operations carried out by Cardenal up to 1893 are of interest; a total of 2,450 operations, with only one case of pyaemia, a very frequent complication in all surgical clinics in the pre-Listerian era.*

The impact of the work of Cardenal was overwhelming and numerous surgeons benefited by the influence of this man, first of all, Moya, ${ }^{* *}$ who collaborated with Cardenal; others are Francisco Rusca, Professor at the Faculty of Medicine of Barcelona, Dr. Duran y Trinchería, ${ }^{* * *}$ Alvaro Esquerdo, $†$ and Vicente Moreno de la Tejera,ft the latter a surgeon at the Military Hospital in Barcelona.

\section{The Faculty of Medicine}

First of all we have Antonio Morales Pérez (born 1858), $+\dagger+$ Professor of Surgery at the Faculty of Medicine of Barcelona. He made a number of contributions to Catalan medical journals on the subject of antisepsis and he accepted the new treatment of Lister. In his work entitled Tratado de Operatoria quiruirgica, 1881-82, containing a brief preface by Juan Creus y Manso, he devoted two lessons to the subject of antiseptics; $\varnothing$ in the first place he considered the value of the cotton-wool dressings of Guérin, the parts of which it consisted and its mode of application, he reported its fundamentals, its advantages and its inconveniences. He then studied antiseptic surgery and the general ideas of Listerism. He stated that wounds could be healed without any unwelcome suppuration; he studied surgical methods that would permit these results to be obtained. He considered a number of antiseptics, such as thymol, salicylic acid, boric acid, etc., and concluded with references to chlorogen treatment, invented according to Morales, by Dr. Cortezo of the Princess Hospital of Madrid.

Enrique Diego de Madrazo ${ }^{124}$ (born in 1850), although a professor at this faculty for only a very short time, in his work published in Barcelona, Lecciones de clinica Quirúrgica, 1888, devoted a complete lesson to a discussion of antiseptic treatment. $\int S$ It was entitled: 'Sepsis and Antisepsis in our Surgical Clinic', and he refers to the new Listerian theory in a concise manner. Some years later he set up in Santander a surgical centre which began to function in 1894 and whence he spread, in the district where he was born, the theory of antiseptics.

Miguel Fargas y Roca (born in 1858), $\iiint$ holder of the Chair of Gynaecology and one of the supporters of antisepsis in Barcelona, was a founder of obstetrics and gynaecology as a speciality. His work is sufficiently explained in words quoted by Cardenal: 'It may be said that he began his career by specialising in antiseptic ovariotomy and that after carrying out a first series of ten ovariotomies, there was only one fatal case.' $\neq$

These operations were carried out in 1886, the year in which he published his

* Ibid., Lec. VI, 202-15.

** Ibid., Lec. XIV, 879.

*** Ibid., 720.

† Ibid., 201, 206, 602.

H Ibid., $201,671$.

Ht See no. 121.

S See no. 200, Lec. XXIII-XXIV, 258-282.

Sf See no. 178, 13-28.

Sós See nos. 207, 255, 310.

† See S. Cardenal (51), 201. 


\section{The Dissemination of Lister's Teaching in Spain}

results. He is fully in agreement with Listerism in his already classic work, Tratado de Ginecologia, where he deals with asepsis and modern antisepsis. He examined matters concerning the preparation of the patient, operating theatres, surgical dress and instruments, dressings and the operating surgeon himself, looking at all these aspects from the point of view of antiseptic theory, together with references to sterilization by means of heat, dry ovens, etc.*

Gil Saltor y Lavall (born 1862), ${ }^{121}$ from Gerona, held the Chair at a number of universities, first that of normal histology and pathological anatomy at Valencia (1889), later at Seville (1890), at Zaragoza (1890-92) and finally at Barcelona (1892), holding the same Chair up till 1895 when he took over the Chair of Surgical Pathology of the Barcelona Faculty. The contribution of Saltor to antisepsis was made in his Estudio sobre el yodoformo en Terapéutica quirúrgica, 1889, a pharmacological contribution which nevertheless contains a good deal of information on the use of iodoform in the field of surgical antisepsis.

We may also add the occasional contribution of some surgeons to Catalan medical journals, such as the papers of Cebeira Rey, Luis Suñe Molist, Moré y Bargit, those of Alvaro Esquerdo, already cited, Alejandro Mackay and Julio Altabás.

\section{VALENCIA: THE FACULTY OF MEDICINE}

There was a group of surgeons at the Faculty of Medicine of this university who accepted and defended with some success the antiseptic doctrine, making quite good contributions to the subject we are studying. Leaving aside the work of Nicolas Ferrer y Julve, Nuevo compendio de Cirugia Menor, 1874, which must be included in pre-Listerian surgery, we find a number of surgeons who were followers of the antiseptic method. First of all Enrique Ferrer y Viñerta** (died 1891), who in 1879 began the treatment of wounds with Lister's method. In his course of clinical surgery, beginning in the academic year $1878-79119$ he dealt with the antiseptic method; it is possible that in this year he actually introduced antisepsis into his professional practice.

Also holders of chairs in this Faculty, although only as visiting professors, were Amalio Gimeno y Cabañas and Francisco de P. Campá, as well as Miguel Sloker de la Pola, who contributed to the diffusion of Listerism. Gimeno, although Professor of Therapeutics, made two clear statements concerning Listerism. In a work that refers to his surgical experience (1879) he made use of Lister's method on a patient. It was an extensive and deep muscle abscess which he filled with an alcoholic solution of carbolic acid. The publication of this work was followed by a letter from Enrique Herraez Aguirre, ${ }^{147-8}$ who stated he had used carbolic acid sprays in the village of Ayelo de Malferit in 1877. On another occasion also Amalio Gimeno in his Tratado Elemental de Terapéutica, 1877-81, included information on antisepsis.

However, the greatest representative of Listerian doctrine in Valencia was Juan Aguilar y Lara, ${ }^{5-10}$ an outstanding pupil of Enrique Ferrer, who was a physiologist and surgeon. In regard to his writings on antiseptic surgery, the earliest correspond to the publications made in the medical journals of Valencia (1878). Of greatest

* pp. 194-222.

** See A. Pulido (224), 301-2; P. Garin (129); and P. Leisteri (175). 
importance is his work already mentioned Lister y Guérin. La nueva Cirugía antiséptica, 1882. The bulk of this work, in itself, is divided into eight basic parts. In the first he gave a bibliography on the subject, a brief history of the antiseptic method, and in the third and last chapter of the first part he studied the fundamental bases of this new antiseptic surgery. The method of Guérin and the practical application of the method of Lister constitutes the theme of the second and third part respectively. In the fourth part he deals with operative surgery according to the precepts introduced by the antiseptic method; in the fifth part, however, he analyses the modifications of antisepsis, and concludes with a series of pathological reports which are listed in the sixth part, and ending with an antiseptic formulation. We can mention others who were supporters of Listerian treatment in Valencia, such as Julio Magraner, José Ma. Machi, etc.

BILBAO

In this city we have the quite exceptional figure of Enrique Areilza y Arregui* (born 1860). Right from the beginning his professional practice was a Listerian one. After having studied at the Faculty of Medicine of Valladolid, he then went to Paris (1879-80) where he attended the medical specialization courses given by Gosellin and Polaillon. Finally, in Bilbao, he directed the hospital group of Triano, Matamoros and Galdames. He was one of the greatest figures in Spanish neurosurgery. His scientific work was fully carried out in the light of the innovation of antisepsis; we recall here the opinion of Cardenal on this surgeon: 'Amongst us, doctor Areilza, eminent director of the mining hospital of Triano, is a supporter of trepanation and has published a series of brilliant cases of cranial fracture so treated. Opposition to this operation in the past has now almost completely disappeared with the progress of antisepsis."** Beginning with his doctoral thesis Areilza was a supporter of Listerism. The title itself gives an idea of the interest of this surgeon in antisepsis: Valor de la cura de Lister en las heridas contusas, Madrid thesis 1880, written when he was twenty years of age. His basic work De las fracturas de cráneo y de la trepanación, Barcelona, 1887, follows this line.

\section{ZARAGOZA}

There were various supporters of Listerism at the Zaragoza Faculty of Medicine. First of all we would mention Francisco Arpal y Daina, ${ }^{* * *}$ born in this city, who refers to antisepsis in his writings. Especially should be mentioned his publications of 1885 and the ovariotomy of 1887 , carried out to Listerian standards. On the other hand, Montells, a Professor at this Faculty, showed a marked hostility to Listerism.

\section{CONCLUSION}

By a fortunate coincidence the news of Lister's discovery was brought to Spain just as the intellectual life of that country, including medicine and surgery, was enjoying the great stimulus given to it by the revolution of 1868 . First propagated by Spanish translations of writings by German and French adherents of Listerism,

* See Luis S. Granjel (140).

* S. Cardenal (51), 563-4.

*** See F. Latassa (152), I, 149. 


\section{The Dissemination of Lister's Teaching in Spain}

it soon found native champions and from the early 1870s several of the younger surgeons began to adopt Lister's principles and methods in their practice, the greatest impetus to its dissemination and acceptance being given by Rubio in the Institute which he founded in Madrid in 1880. Outstanding however was the work of Cardenal, who visited Lister at King's College Hospital in 1883 and assisted in his clinic. He and other Spanish surgeons realized very quickly that Bergmann's 'asepsis' was merely an extension of Lister's doctrine, which, by 1890 was generally recognized and used in all imporant Spanish surgical centres. Its role in promoting the development of surgical specialities (gynaecology, ophthalmology, etc.) in Spain is also made clear.

\section{REFERENCES}

1. 'Acido fénico: usos terapéuticos', An. Med. Cirug. práct., Madrid, 1869, 5, 612-13.

2. Actas de la primera sesión del Congreso Hispano-portugués de Cirugía y sus especialidades naturales celebrado en Madrid (Abril de 1898), Madrid, 1899.

3. 'El Agua oxigenada como antiséptico', An. int. Med. Cirug., Madrid, 1899, 29, 164-65.

4. Aguilar Blanc, José, 'De las duchas antisépticas en las supuraciones de la córnea', Crónica méd. (Revta quinc. Med. Cirug. práct.), Valencia, 1883, 7, 69-70.

5. Agullar y lara, Juan, 'La nueva cirujía antiséptica', Crónica méd. (Revta quinc. Med. Cirug. práct.), Valencia, 1878, 1, 579-85, 615-20, 687-89.

6. - 'Las curas con el papel de seda', Siglo méd., 1880, 27, 439-41.

7. - 'Tratamiento de las heridas. Cura de Guerin', Crónica méd (Revta quinc. Med. Cirug. práct.), Valencia, 1880, 3, 605-10.

8. - 'Consideraciones históricas sobre las curas antisépticas en Cirujia', Crónica méd. (Revta quinc. Med. Cirug. práct.), Valencia, 1881, 4, 646-49.

9. - Lister y Guerin. La nueva Cirujia antiséptica. Historia, Principios, Manual operatorio y Resultados, Valencia, 1882.

10. - 'Las curas con el papel de seda', Crónica méd. (Revta quinc. Med. Cir. práct.), Valencia, 1884, 8, 140-45.

11. ArCart y Lopez, LoRenzo, La Cirugia antiséptica, Madrid, 1884.

12. Albarran, J., 'Lecciones de Clínica quirúgica por el Professor Dr. E. Diego de Madrazo. Barcelona 1888' (Reseña a este libro), Gac. méd. catal., 1889, 12, 631-33.

13. Altabas, Julro, 'Cirugia antiséptica: una sala de operaciones en la casa de curación quirúrgica del Doctor Cardenal', Siglo méd., 1890, 37, 458-60, 473-75, 1890.

14. 'La ovariotomía en Barcelona', Siglo méd., 1890, 37, 534-36, 551-53, 565-68, 582-86, 597-601, 614-17, 632-35, 651-54, 663-66, 695-99, 793-96.

15. Alvarez SIERRA, José, Médicos madrileños famosos. Blografia y Bibliografia de Médicos ilustres nacidos en Madrid y su Provincia, Madrid, 1934,.

16. - El Doctor D. Federico Rubio. Vida y Obra de un Cirujano genial, Madrid, 1947.

17. —_ 'El 11 de noviembre de 1908, en el anfiteatro de San Carlos, la autopsia del doctor San Martín', Consejo General de Colegios Médicos. Boletín Cultural e Informativo: XXI: 125, 45-48; Madrid, 1958.

18. - 'Diccionario de cirujanos españoles, hispano-americanos y filipinos'; Cirug. Ginec. Urol., 1959-61, 13, 4: 2-15; 5: 32-51; 6: 70-85; 14, 1: 2-15; 41-57; 3: 82-97; $4: 116-31 ; 5: 164-83 ; 6: 200-215 ; 15,1: 4-19 ; 2: 46-61 ; 3: 94-109 ; 4: 138-47$;

19. - Historia de la Academia médico-quirúrgica española, Madrid, 1964.

20. ANDREWS, M. L., Lord Lister (1827-1912), London, 1953.

21. 'Antisepsia quirúrgica', An. int. Med. Cir., 1899, 30, $152-53$.

22. 'Antisepsis en general $i$ cómo obran los antisépticos ? (Tema oficial del Congreso de Ciencias médicas de Barcelona, 1888)', Gac. méd. catal., 1889, 12, 129-32.

23. Arritza y ARregur, EnRIQue, 'Valor de la cura de Lister en las heridas contusas', Madrid thesis, 1880. 


\section{Juan Riera}

24. - De las Fracturas de Cráneo y de la Trepanación. Estudio clínico, Barcelona, 1887.

25. ArPal y DaINa, Francisco, 'Herida por arma de fuego (reseña de una intervención del Dr. León Corral)', Siglo méd., 1885, 32, 675-77.

26. - Primera Ovariotomía practicada en Zaragoza, Zaragoza, 1887.

27. - Lecciones de Terapéutica quirúrgica general, Zaragoza, 1890.

28. - Estadistica operatoria del Dr. Arpal, desde 1872 a 1899, Zaragoza, 1899.

29. 'Asepsia y antisepsia en obstetricia', Siglo méd., 1886, 33, 758.

30. Badia, Salvador, Cartas médico-quirúrgicas escritas sobre el terreno con motivo de la Gierra Franco-Prusiana de 1870-71, Barcelona, 1872.

31. BaezA, B. V., 'Un nuevo podersoso antiséptico: La helemina', Crónica méd. (Revta quinc. Med. Cirug. práct.), Valencia, 1885, 8, 293-98, 330-35.

32. Barbera, Faustino, 'El Dr. D. Federico Rubio y su jubileo profesional', Revta valenc. Cienc. méd., 1899, 2, 193-94.

33. Barbera, Faustino, 'Valenciano ilustre' (semblanza de Eulogio Cervera Ruiz), Revta valenc. Cienc. méd., 1899, 2, 370-71.

34. Bergman, 'La asepsia en Cirugia', An. Med. Cirug. práct., Madrid, 1890, 12, 378-80.

35. Bibliografia Medical de Catalunya, Barcelona, 1918.

36. Blan y BeNET, José, Datos para una Biblioteca quirúrgica española, Barcelona, 1895.

37. Blonder, Dr., 'De la desinfección de las heridas de sutura por alcohol', An. int. Med. Cirug. Madrid, 1897, 26, 364-66.

38. C: 'Accidentes debidos a las substancias antisépticas más usuales', Siglo méd., 1887, 34, 555-56.

39. C.M.C.: 'Curas por iodoformo', Siglo méd., 1878, 25, 577.

40. Calvo Cubells, 'Cuatro palabras más acerca de la helenina', Crónica méd. (Revta quinc. Med. Cirug. práct.), Valencia, 1885, 8, 402-4.

41. Calvo y Martin, José, 'Presidentes de la Real Academia Nacional de Medicina. Excmo. Sr. D. Calvo y Martin', Real Acad. Nac. de Med. Boletín Informativo, no 85, Madrid, 1957.

42. Cameron, H. C., Joseph Lister, London, 1948.

43. Campa, Francisco De P., 'Antisepsis obstétrica', Congreso de Ciencias Médicas de Barcelona, II: 736-45, Barcelona, 1888.

44. - 'Sobre la antisepsia preventiva puerperal en los partos normales', Crónica méd. (Revta quinc. Med. Cirug. práct.), Valencia, 1888, 12, 65-72, 99-106.

45. Cardenal Fernandez, Salvador, Guia práctico para la cura de las heridas y la aplicación del método antiséptico en Cirugia. Lecciones dadas en la Acad. y Laboratorio de Ciencias Medic. de Cataluña. Barcelona, Espasa Hnos. (s.a.) (Esta obra parece haber sido edit. en 1879).

46. - 'Un caso más en pro de los adelantos de la Cirugía moderna', Gac. méd. catal., $1878,1,65-71$.

47. — 'Tratamiento antiséptico del empiema', Gac. méd. catal., 1879, 2, 153-54.

48. - 'Operación cesárea y el método antiséptico en Francia', Gac. méd. catal., $1879,2,509$.

49. ——, 'Nuevos aparatos e instrumentos', Gac. méd. catal., 1879, 2, 589-91.

50. - Manual práctico de Cirugia antiséptica, Barcelona, 1887.

51. —- Manual práctico de Cirugía antiséptica, 3rd ed., Barcelona, 1894.

52. - Contribución al estudio de los Efectos de los modernos Proyectiles de Guerra y su Tratamiento, Barcelona, 1895.

53. - Clinicum. Casa de curación quirúrgica del Dr. C., Barcelona, 1899.

54. (Carcan, Decio), 'Academia Médico-quirúrgica', Siglo. méd., 1880, 27, 33-35.

54a. Carreras-Arago, Dr., 'La septicemia ocular' (conferencia dada el 11 de Abril de 1880 en el Hospital de San Juan de Dios de Cádiz por el Ilmo. Sr. Dr. Cayetano del Toro y Quartillers. Cádiz, 1880)', Gac. méd. catal., 1880, 3, 557-60.

55. Casagemas, S., 'La Cirugía ocular antiséptica en la clínica del Dr. J. Barraquer', Gac. méd. catal., 1882, 2, 325-33. 


\section{The Dissemination of Lister's Teaching in Spain}

55a. Castañeda, T., 'Apósito de Lister. Modificaciones del doctor Bardenheuer', Siglo méd., 1879, 26, 206-7.

56. Castella, A., 'El doctor Salvador Cardenal (1852-1927)', An. Med., 1928, 22, 338-52.

57. Castells Ballespi, Federico, 'Antisepsis quirúrgicas: solubilidad del ioduro mercúrico', Revta Med. Cirug. práct., Madrid, 1885, 16, 134.

58. 'Catgut fenicado de Lister', Siglo méd., 1880, 27, 121.

59. Causas, 'Las causas de la muerte después de las heridas. Higiene hospitalaria', Siglo méd., 1875, 22, 203-4.

60. CEA, LeOPOLdo, Apositis y Vendajes antisépticos, Valladolid, 1888.

61. Cebrira Rey, 'Agua oxigenada: su empleo como agente antiséptico', Gac. méd. catal., 1883, 6, 297.

62. Clorarum, 'El clorarum como antiséptico', Siglo. méd., 1874, 21, 698.

63. Colet, M., 'Salvador Cardenal', Med. catal., 1934, 2, 417-18.

64. 'Colodion antiséptico cloralado', Siglo méd., 1875, 22, 220.

65. 'Congreso Médico Internacional de Sevilla', Gac. méd. catal., 1882, 2, 459.

66. 'Congreso Regional de Ciencias Médicas de Cádiz', Siglo méd., 1879, 26, 569-71.

67. 'Congreso Regional de Ciencias Médicas de Cáadiz', Gac. méd. catal., 1879, 2, 566-69, 592-602, 631-33, 652-60.

68. Congresos de Ciencias Médicas de Barcelona celebrados del 9 al 15 de septiembre de 1888, 2 vols., Barcelona, 1889.

69. Corachan, M., 'El doctor Cardenal, cirujano', An. R. Acad. Med. Cirug. Barcelona, 1928, 3-9.

70. Cortejarena, Francisco, Mis bodas de oro con la Profesión, 1859-1909, Tiempo pasado, Madrid, 1909.

71. CReus y Manso, Juan, 'Sarcoma de antebrazo', Siglo méd., 1880, 27, 8-10.

72. Historias de clinica quirúrgica recogidas durante los cursos de 1877 a 1880 , en la clinica del Dr. Creus y Manso, Madrid, 1880.

73. — 'Prólogo', Tratado de Operatoria quirúrgica del Dr. Morales Pérez, vol. 1, Barcelona, 1881.

74. —_, 'Introducción', Enciclopedia Internacional de Cirugia del Dr. Ahhurst, vol. 1, Madrid, 1883.

75. —-, 'Enfermedades quirúrgicas infecciosas en general', Enciclopedia Internacional de Cirugia del Dr. Ashhurt, vol. 1, Madrid, 1883.

76. 'Cura al descubierto en las amputaciones osteoplásticas de Pirogoff y Gritti', An. Cienc. méd., Madrid, 1877, 4, 109-10.

77. 'Cura permanente', Siglo méd., 1885, 32, 61-62.

78. 'Curacion de las grandes heridas por las preparaciones de ácido fénico método de Lister', Siglo méd., 1870, 17, 152.

79. 'Las Curas de las heridas' (Real-Academia de Medicina, sesión 12-III-1881), Revta Med. Cirug. práct., Madrid, 1881, 8, 272-73, 67-78.

80. Curas, 'Las curas de las heridas' (Real Acad. de Med., 23-IV-1881), Revta Med. Cirug. próct., Madrid, 1881, 8, 561.

81. Curas, 'Las curas de Lister' (Por Lucas-Championniére), An. Cienc. méd., Madrid, 1876, 2, 193-97, 225-30.

82. Championniere, Lucas, Cirugía antiséptica, (trans. by Vélez y Martínez), Madrid, 1877.

83. Lacalle, (s.1.), 1881.

84. 'Desinfeccion de la sesponjas que se emplean en el lavado de las heridas', Siglo méd., $1872,19,323$.

85. 'Determinar los casos en que, siendo arriesgada la extracción del proyectil en heridas por armas de fuego, debe prescindirse de ella mediante la cura antiséptica', Gac. med. catal., 1891, 14, 11-12. 


\section{Juan Riera}

86. Diaz Gomez, E., 'Don Enrique de Isla y Bolumburu', Hospital General, Madrid, 1963, 3, (1), 1-4.

87. Dukes, C., Lord Lister, 1827-1912, London, 1925.

88. EliAs DE Molins, ANTONIO, Diccionario biográfico y bibliográfico de escritores y artistas catalanes del siglo XIX (Apuntes y datos), 2 vols., Barcelona, 1889-95.

89. EnCINAS, SANTIAGo, Metodolgía y principios generales de Clínica Quirúrgica, Madrid, 1883.

90. Escribano Garcia, Victor, Datos para la Historia de la Anatomía y Cirugía española en los siglos XVIII y XIX, Granada, 1916.

91. - 'Notas y recuerdos de la época de Cajal', Boletín de la Universidad de Granada, 1952, 24, 20-40.

92. Espina y CAPO, Antonio, 'De las curas antisépticas del Doctor Lister', Revta Med. Cirug. práct., Madrid., 1878, 3, 159-65.

93. —_-, 'Discusión sobre el método de Lister', ibid., 1879, 5, 42-46.

94. — 'De la cura de las heridas', ibid., 1879, 5, 181-87.

95. — - 'De las curas antisépticas', ibid., 1879, 5, 283-87.

96. — - 'Cura de Lister', ibid., 1879, 4, 524-25.

97. _ 'Discusión sobre las curas de Lister y la cura con alcohol', ibid., 1879,4, 568-72.

98. — - 'Cura de Lister', ibid., 1880, 6, 301.

99. - 'Resultados de la cura por el bismuto en el Hospital de Tis-la Chapelle, durante los tres primeros meses de 1883', ibid., 1883, 13, 564-75.

100. —-, 'Acción antiséptica de las sales de cobre', ibid., 1883, 13, 559-60.

101. - 'Ligadura en la continuidad de las arterias por medio del catgut', ibid., 1885, 16, 104.

103. - 'Cura permanente de las heridas (Neuber)', ibid., 1885, 16, 258-60.

104. 'Aplicación del método antiséptico en Cirugia ocular', ibid., 1885, 16, 485-88.

105. - 'Antisepsis', ibid., 1886, 19, 471.

106. _La antisepsis en general' (Congreso Médico de Barcelona, 10-IX-1888), ibid., 1888, 23, 592-96.

107. _- 'Antisepsis en general ¿ Cómo obran los antisépticos?', Congreso de Ciencias Médicas de Barcelona, 1889, 2, 63-78.

108. - 'De la antisepsia y de la asepsia en Cirugía (Sobre el estado de la Cirugia antiséptica, J. Lister, autor)', Revta Med. Cirug. práct., Madrid, 1891, 28, 46-49.

109. - Notas del Viaje de mi Vida, IV, Madrid, 1929.

110. Esquerdo y Esquerdo, Alvaro, 'Herida por arma de fuego: fractura conminuta de maxilar inferior. Curación', Gac. méd. catal., 1878, 1, 337-43.

111. 'Esterilizacion por el calor en Cirugía', Gac. méd. catal., 7, 537-71.

112. 'Esterilizacion de los instrumentos en Cirugia', An. int. Med. Cirug., Madrid, 1897, 26, 146-47.

113. Fargas y Roca, Miguel, Primera serie de diez Ovariotomias, Barcelona, 1886.

114. _ 'Antisepsis obstétrica' (comunicación oral), Congreso de Ciencias Médicas de Barcelona, pp. 743 ff. Barcelona, 1888.

115. Fedorof, 'Tratamiento de las heridas por la glicerina', An. int. Med. Cirug., Madrid, 1894, 19, 233-35.

116. Fernandez Almagro, Melchor, 'El doctor Creus', Medicamenta, Madr., 1947, 8, $129,17-18$.

117. Fernandez Casadevante, M., Algodones y gasas medicinales empleados en la cura antiséptica, Barcelona, 1896.

118. Fernandez Victorio, A., Lecciones de Patología quirúrgica, tomadas de viva voz de las explicaciones del Catedrático Dr. Creus, Madrid, 1886.

119. FERRER y VIÑERTA, EnRrQue, Curso de Clínica quirúrgica de la Facultad de Medicina de Valencia (1878-79), Valencia, 1879. 


\section{The Dissemination of Lister's Teaching in Spain}

120. Forgue, E. (de Montpellier), 'Sobre la esterilización de los hilos; un modelo de devanadera esterilizadora para los hilos de suturas y ligaduras', An. int. Med. Cirug., Madrid, 1893, 17, 370-75.

121. Gallart Mones, F., 'Los catedráticos de la Facultad de Medicina durante mis estudios (1897-1901)', Jornadas Conmemorativas del Cincuentenario del Hospital Clínico y Provincial de Barcelona (1907-1957), Barcelona, 1959, pp. 33-45.

122. Garcia Del Carrizo, M. Gloria, 'Historia de la Facultad de Medicina de Madrid (1843-1931)', Madrid thesis, 1963.

123. Garcia Lopez y Garcia, CAsimiro, 'Breves apuntes sobre la cura de las heridas', Siglo méd., 1883, 30, 7-12.

124. Garcia Del Moral, Jose, Galeria de escritores médicos montañeses, Santander, 1906.

125. Garcia Del Real, Eduardo, Historia de la Medicina en España, Madrid, 1921.

126. - 'Don Federico Rubio y Gali', Gac. méd. esp., 1927, 2, (4), 35-6.

127. Garcia Teresa, 'Quiste de ovario. Ovariotomía. Empleo de la cura de Lister. Curación', Revta Med. Cirug. práct., Madrid, 1879, 5, 81-82.

128. Garin, P., 'El ácido bórico en Cirujía', Crónica méd. (Revta quinc. Med. Cirug. práct.), Valencia, 1884, 8, 101-5.

129. _ 'El Dr. Enrique Ferrer y Viñerta', ibid., 1891, 15, 51-55.

130. Gil Novales, Alberto, 'Federico Rubio y Gall', Las pequeñas atlántidas, Barcelona, 1959, pp. 173-83.

131. Gimeno, Amalio, 'Aplicación del método de Lister al tratamiento de un absceso extenso y profundo del muslo', Crónica méd. (Revta quinc. Med. Cirug. práct.), Valencia, 1879, 2, 518-26.

132. Gimeno y Cabañas, Amalio, ‘Alejandro San Martín', Antología del Professor Amalio Gimeno y Cabañas, 691-98, Madrid, 1935.

133. GODLEe, R. J., Lord Lister, 2nd ed., London, 1918.

134. Gonzalez Tarrago Y Garcia, Manuel, 'Concepto que de la asepsia se tiene en España', Actas de la Primera sesión del Congreso Hispano-portugués de Cirugia, Madrid, 1899, 53-57.

135. Goyanes Capdevilla, J., 'El doctor Alejandro San Martín', Rev. ib.-am. Cienc. méd., 1908, 20, 321-26.

136. Granjel, LuIs S., Historia de la Medicina Española, Barcelona, 1962.

137. - and SANTANDER, M. TERESA, Indice de Médicos españoles, Salamanca, 1962.

138. _ Bibliografía histórica de la Medicina Española, Salamanca, vol. 1 (1965), vol. 2 (1966).

139. —-, Médicos Españoles, Salamanca, 1967.

140. - 'El Doctor Areilza y Arregui' (in press).

141. GUTHRIE, D., Lord Lister: his Life and Doctrine, Edinburgh, 1949.

142. GuTIERREZ, EugenIo, 'Observación de una ovariotomía singular', Siglo méd., 1885, 32, 114-17.

143. - Biografia del Excmo. e Ilmo. Sr. D. Federico Rubio y Gali, Madrid, 1903.

144. Heridas, 'Tratamiento de las heridas', An. int. Med. Cirug., Madrid, 1897, 25, 154-56.

145. - 'Heridas: tratamiento por el eter pulverizado, el calor y el ácido fénico', Anu. Med. Cirug. práct., Madrid, 1869, 5, 418-20.

146. Hernandez Poggio, Ramón, 'La Cirugía antiséptica en los campos de batalla', Siglo méd., 1881, 28, 243-46, 257-59, 274-77.

147. Herraez Aguirre, Enrique, 'Cirugia antiséptica', Crónica méd. (Revta quinc. Med. Cirug. práct.), Valencia, 1879, 2, 589-96.

148. - 'Heridas por mordedura, complicada con fractura doble y conminuta de los huesos del antebrazo. Podedumbre hospitalaria. Síndrome de piohemia. Curación', Siglo méd., 1881, 28, 10-11, 41-44.

149. 'Instrumental aséptico de Schwabe', An. int. Med. Cirug., Madrid, 1893, 17, 345-48.

150. Jimeno Egurvide, Prontuario de Cirugía asépto-antiséptica. La Cirugía moderna: sus principios, procedimientos y resultados, Pamplona, 1890. 


\section{Juan Riera}

151. LARra y Cerezo, ANgel, Historia resumida del Periodismo médico en España, Madrid, 1905.

152. LATASSA, FÉLIX DE, Bibliotecas antigua y nueva de escritores aragoneses de Latassa. Aumentadas y refundidas en forma de diccionario bibliografico-biográfico por Don Miguel Gómez Uriel, 3 vols., Zaragoza, 1884-86.

153. LeEsON, JoHN RUDD, Lister as I knew him, New York, 1928.

154. Libro en Honor del Dr. Juan Creus y Manso, Granada, 1928.

155. Lister, JosePH, 'On the early stages of inflamation', Phil. Trans. $R$. Soc., 1858, 148, 645-702.

156. - 'On the coagulation of the blood', Proc. R. Soc., 1863, 12, 580-611.

157. - 'On a new method of treating compound fracture, abscess, etc., with observations on the conditions of suppuration', Lancet, 1867, i, 326-29, 357-59, 387-89, 507-9; ii, 95-96 (reprinted Med. Classics, 1937, 2, 28-71).

158. - 'On the antiseptic principle in the practice of surgery', Lancet, 1867, ii, 353-56, 668-69 (reprint in Med. Classics, 1937, 2, 72-83).

159. - 'Observations on ligature of arteries on the antiseptic system', Lancet, 1869, i, 451-55.

160. surgical hospital', Lancet, 1870, i, 4-6, 40-42 (reprint in Med. Classics, 1937, 2, 84-101).

161. 'A method of antiseptic treatment applicable to wounded soldiers in the present war', Brit. med. J., 1870, ii, 243-44.

162. -, 'A further contribution to the natural history of bacteria and the germ theory of fermentative changes', Quart. J. micr. sci., 13, 380-408, 1873.

163. - 'On the lactic fermentation and its bearing on pathology', Trans. path. Soc. Lond., 1877-78, 29, 425-67.

164. - 'An address on the catgut ligature', Trans. clin. Soc. Lond., 1881, 14, xliii-lxiii.

165. - Oeuvres réunies de Chirurgie, Brussels, 1882.

166. - (trans. Dr. Ossio), 'Relación de los microorganismos con la inflamación', Siglo méd., 1881, 28, 693-94, 724-25, 759-61.

167. Sociedad Médica Londinense el 4 de noviembre de 1889), Siglo méd., 1889-90, 36, 804-6; 37, 84-86.

168. - 'Estado actual de la Cirugía antiséptica', Crónica méd. (Revta quinc. Med. Cirug. práct.), Valencia, 1889-90, 13, 506-9.

169. - 'Uso del cianuro de zinc y de mercurio en las curas antisepticas', An. Med. Cirug. práct., Madrid, 1890, 11, 395-400.

170. LOPEZ OCAÑa, J., 'Cirugia ocular antiséptica', Gac. méd. catal., 1880, 3, 385-87.

171. - 'La terapéutica antiséptica en Oftalmologia', Siglo méd., 1880, 27, 166-67.

172. LoPEZ PIÑERo, José M., 'La comunicación con Europa en la Medicina española del siglo XIX', Almena, 1963, 2, 33-64.

173. - 'Los comienzos en España de la moderna neurocirugla durante los últimos años del siglo XIX y los primeros del XX', La Trepanación en España, Madrid, 1967, pp. 309-480.

174. LuIs Y YaGÜв, R., 'Don Federico Rubio y Gali', Siglo méd., 1925, 76, 585-88.

175. LlISTERI FERRER, PRÁXEDES, Recuerdo apológético del Dr. Enrique Ferrer y Viñerta, Valencia, Instituto Médico Valenciano, 1919.

176. Lloret, 'Contribución a la práctica de la antisepsis. El jabón antiséptico', Crónica méd. (Revta quinc. Med. Cirug. práct.), Valencia, 1890, 13, 40.

177. MaCkay, Alejandro, 'La ovariotomía en Barcelona', Siglo méd., 1890, 37, 678-80.

178. MAdrazo, EnRIQUe DIRgo DE, Lecciones de Clínica Quirúrgica dadas en la Facultad de Medicina de Barcelona, Barcelona, 1888.

179. - Memoria y Estadistica operatoria del primero, segundo y tercer año del Sanatorio quirúrgico Madrazo, Santander, 1898. 


\section{The Dissemination of Lister's Teaching in Spain}

180. Marco, LuIs, 'Fallecimiento de nuestro director (semblanza de Federico Rubio y Gali)', Revta ib.-am. Cienc. méd., 1902, 8, i-viii.

181. Mariani y LaRrion, Juan Manuel, 'La cura de las heridas' (Real Acad. de Medicina, sesión 5-II-1881), Revta Med. Cirug. práct., Madrid, 1881, 8, 227.

182. - 'Empleo del agua oxigenada en Cirugía. Las curas con iodoformo', ibid., $1883,12,19-21$.

183. _- 'De la eficacia antiséptica de la cura por la gasa con thymol', ibid., 1883, $12,136$.

184. - 'Cura antiséptica de los heridos en aparato de cristal', ibid., 1883, 13, 156.

185. —- 'Un nuevo poderoso antiséptico: la helenina', ibid., 1885, 16, 428-29.

186. — - 'Irrigador del Dr. Osío para el completo lavado y asepsia del fondo de saco conjuntival y de la córnea', ibid., 1885, 17, 369-40.

187. —_ 'Nueva cura antiséptica en campaña', ibid., 1886, 18, 46.

188. — 'El sublimado como antiséptico', ibid., 1886, 19, 40-41.

189. — 'El hidro-naftol nuevo antiséptico', ibid., 1886, 19, 244.

190. Martin de Prados, Antono, Alejandro San Martín Sartústegui. Sy aportación a la Cirugía, Madrid, 1956.

191. Martinez-Bargas, A., 'Sesiones literarias celebradas en el segundo semestre de 1882 por el cuerpo médico-farmacéutico de la Beneficencia Provincial. Sesion del 2 de diciembre de 1882', Revta Med. Cirug. práct., Madrid, 1883, 12, 34-42, 81-85, 179-184.

192. Mateo Barcones, E., La Cirugia antiséptica, Madrid, 1888.

193. Mendez Alvaro, V. F., Breves apuntes para la Historia del periodismo médicos y farmacéutico en España, Madrid, 1883.

194. 'Otro Metodo de curación de las heridas', Siglo méd., 1874, 21, 779-80.

195. Micro-organisms, 'Los micro-organismos en el pus de las heridas', Siglo méd., 1875, 22, 121-22.

196. MIRANDA Bistuer, V., Cura antiséptica. Manual práctico y formulario para la preparación de todos los materiales que en la actualidad se emplean en las curaciones antisépticas, Madrid, 1890.

197. Montalban, Francisco, 'Lecciones sobre el tratamiento de las heridas dadas en el Hospital de la Caridad por M. Trelat', Siglo méd., 1878, 25, 26-28, 42-44, 90-92, 101-104.

198. Morales Perez, Antonio, 'Listerófobos y Listerófilos', Gac. méd. catal., 1881, 1, 310.

199. - 'El sistema de Lister', ibid., 1881, 1, 312-13.

200. Tratado de Operatoria quirúrgica, 2 vols., Barcelona, 1881-82.

201. - 'El Dr. Cardenal Fernández', Siglo méd., 1927, 79, 586-87.

202. MORE y BARGIT, 'Contribución el estudio del ácido salicilico y sus compuestos', Gac. méd. catal., 1882, 2, 333-38.

203. Mowbray Barberan, Julio, 'Estudio biográfico del Dr. D. Juan Creus y Manso', Trab. Cat. Hist. Crit. Med. Univ. Madr., 1936, 7, 27-37.

204. Murillo, Palacios, and Zabalegui, Simonea, Lecciones de la Clínica Quirúrgica dadas en la Facultad de Medicina de Barcelona por el Catedrático de la asignatura Dr. D. Madrazo, Barcelona, 1888.

205. NADAL, JoAQUIN M., 'El doctor Cardenal', Recuerdos de medio siglo. Siluetas y perfiles barceloneses, Madrid, 1957, pp. 257-61.

206. 'Nuevo método de oclusión antiséptica de las heridas', Siglo méd., 1874, 21, 825-26.

207. Nubiola, P., 'Rememorando al maestro Fargas', Med. clin., Barcelona, 1948, 11 (3), 204-7.

208. Nussbaum, J. N., Lecciones de Clinica quirúrgica, Madrid (c. 1887).

209. - Cura antıséptica expuesta según el método de Lister, traducida por Emilio Reina Martin y Gonzalo Angulo Laguna, Sevilla, 1880.

210. __ 'Lecciones de Clínica Quirúrgica', Siglo méd., 1887, 34, 424-26. 


\section{Juan Riera}

211. Olvan y Sanz, E., Algunas reflexiones encaminadas a demostrar que la confianza que en la actualidad inspiran la anestesia y el empleo de los modernos métodos antisépticos, no justifica ni disculpa la práctica hoy demasiado repetida de las operaciones y muy especialmente de las llamadas laparotomias exploradoras, Madrid, 1889.

212. Ossio, Dr., 'Del método antiséptico en Cirugía ocular', Siglo méd., 1881, 28, 631.

213. Osio, Dr., 'Irrigador del Doctor Osío para el completo lavado y asepsia del fondo de saco conuntival y de la córnea', Siglo méd., 1885, 32, 752-53.

214. P., 'De la antisepsia en Alemania', Siglo méd., 1884, 31, 151-53.

215. Pareja Garrido, José, 'Recuerdos de un alumno de D. Juan Creus y Manso', Actualidad méd., Granada, 1935, 21, 253-56.

216. Pego Busto, ARmando, 'Vida y obra del cirujano José Ribera y Sans' (1852-1912)', Arch. ib.-am. Hist. Med., 1951, 3, 205-63.

217. Perez-Cascon Cobos, Adolfo, 'Don Salvador Cardenal, introductor en España del método antiséptico', Madrid thesis, 1957.

218. Perez Ortiz, J., Cirugía de Urgencia, Madrid, 1895.

219. - Memorias de Cirugia, Personalidades quirúrgicas en Francia y Suiza. Concepto actual del cirujano, asepsia y antisepsia, del uso de guantes, Hemostasia, Madrid, 1904.

220. Peset y Cervera, Vicente, 'Valor relativo de las sustancias antisépticas', Crónica méd. (Revta quinc. Med. Cirug. práct.), Valencia, 1884, 7, 289-95.

221. Pr Suñer, DR., 'Casos de fracturas de huesos con herida exterior. Indicaciones (Hospital de Sta. Cruz)', Gac. méd. catal., 1878, 1, 22-28.

222. Poblacion, ANTonio, 'Estracción arriesgada del proyectil. Cura antiséptica en estos casos', Congreso Med. Internacional de Barcelona, 1888, (Cit. by Blanc y Benet).

223. 'Prensa extranjera: operación cesárea seguida de amputación útero-ovárica', Siglo méd., 1878, 25, 587-88.

224. Pulido y Fernandez, Angel, De la medicina y los médicos, Valencia, 1883.

225. - 'Grandes conquistas de la Medicina', Siglo med., 1885, 32, 178-82, 290-91, $306-8$.

226. ——, 'El Dr. D. Francisco de Cortejarena', Siglo, méd., 1919, 76, 118-20.

227. 'Real Academia de Medicina', Siglo méd., 1890, 37, 113.

228. Reina, Eduardo, 'Valor comparativo de la asepsis y de la antisepsis en Cirugia ocular', Congreso de Ciencias Médicas de Barcelona, 1889, 2, 727-36.

229. Ribera y Sans, José, 'La cura antiséptica', Revta Med. Cirug. práct., Madrid, 1886, $19,50$.

230. — 'Del empleo del algodón de turba para las curas', ibid., 1887, 20, 609.

231. — - 'Manual de Cirugía antiséptica,' ibid., 1887, 21, 251-59.

232. ___ 'Estudio de las relaciones reciprocas entre los estados morbosos generales y las lesiones quirúrgicas', An. R. Acad. Med., Madr., 1888, 8, 300-90.

233. - 'Cirugía antiséptica: supresión de desagüe', Revta Med. Cirug. práct., Madrid, $1889,25,102-3$.

234. - 'Modificación práctica del método antiséptico', ibid, 1889, 25, 435.

235. —_ 'Detalles estadísticos de la clínica quirúrgica (segundo curso) desde $1^{\circ}$ de octubre de 1890 hasta 30 de junio de 1891, ordenado por el Dr. D. César Cabañas', ibid, 1891, 29, 174-81, 236-43, 346-55, 462-60, 625-34.

236. - Clínica quirúrgica. Consideraciones generales sobre la etiología, el diagnóstico, pronóstico y tratamiento de los enfermos quirúrgicos, Madrid, 1895.

237. - Clínica quirürgica general, Madrid, 1898.

238. - Elementos de patología quirúrgica general, Madrid, 1900.

239. Rodriguez Mendez, Rafael, 'Propiedades antisépticas del ácido pirogálico', Gac. méd. catal., 1879, 2, 250.

240. ㄴ 'Valoración del poder antiséptico del iodo', Revta Med. Cirug. práct., Madrid, $1883,13,452-53$.

241. — 'Iodoformo fenicado', Gac. méd. catal., 1883, 6, 715. 


\section{The Dissemination of Lister's Teaching in Spain}

242. - 'Inaplicación terapéutica a la antisepsia interna por D. Nicolás Rodríguez Abaytua. Madrid, 1888', ibid., 1889, 12, 373.

243. - 'Microbios y abscesos: clasificación de estos últimos', ibid., 1889, 12, 637-38.

244. Roos, Edvin, 'Sobre el desagüe de las heridas', An. int. Med. Cirug., Madrid, 1894, 18, 414-16.

245. Rubio, FeDERICo, 'Sobre el examen microscópico del vapor atmosférico de la enfermería del doctor Martín de Pedro en el Hospital General', Siglo méd., 1872, 19, 404-7, 418-21, 435-37.

246. - 'Indicaciones acerca del drenado en la terapéutica operatoria', Siglo méd., 1877, 24, 725-26.

247. - Reseña del primer ejercicio del Instituto de Terapéutica operatoria del Hospital de la Princesa, Madrid, 1881.

248. - ARIza y Espejo, Rafael, and Buisen, Serafín, Reseña del segundo ejercicio del Instituto de Terapéutica Operatoria, Madrid, 1882.

249. — ARIZA y ESPEJo, RAfael, BuISEN, SERAfín, and Gutierrez, Eugenio, Reseña del tercer ejercicio del Instituto de Terapéutica Operatoria, Madrid, 1883.

250. - ARIZA y Espejo, RAfael, BuISEN, Serafin, and Gutierrez, Eugenio, Reseña del cuarto ejercicio del Instituto de Terapéutica Operatoria, Madrid, 1884.

251. Ruiz De Lara, Antonio, 'D. Federico Rubio y Gali', Trab. Cat. Hist. Crit. Med. Univ. Madr., 1934, 3, 367-74.

252. RUYTER (Ayudante de Bergmann), 'La asepsia en vez de la antisepsia', Siglo méd., 1890, 37, 523-24.

253. SAleEby, C. W., Modern Surgery and its Makers: a Tribute to Listerism, London, 1911.

254. Saltor y LAVAll, G., Estudio sobre el yodoformo en Terapéutica quirúrgica, Barcelona, 1889.

255. Salvat Espasa, Manuel, 'Miguel A. Fargas i Roca', Med. catal., 1935, 5, 121-22.

256. SAN MARTIN, A., Curso de patología quirúrgica, Madrid, 1883.

257. - Clínica quirúrgica de la Facultad de Medicina de Madrid, Madrid, 1893.

258. _ 'Un nuevo método de amputación de las extremidades inferiores', Actas . . . Congreso Hispano-portugués, Madrid, 1899, pp. 403-22.

259. SANChez De La Cuesta, GABRIEL, Ideario y Grandeza de don Federico Rubio, Sevilla, 1949.

260. Sanchez Perez, Jesús, 'Don Salvador Cardenal y Fernández, cirujano español del siglo XIX', An. Univ. Madrid (Sec. Cien.), 1934, 3 (3), 249-69. (Reprinted in Trab. Cat. Crit. Hist. Med. Univ. Madr., 1935, 5, 79-98.)

261. SANChez Rubio, E., Bibliografia médica española contemporánea (1880-1904), Madrid, 1901.

262. SchÄFfer, R., 'Estudios experimentales sobre la asepsia', An. int. Med. Cirug., Madrid, $1898,28,378-81$.

263. SERRET, RAMón, 'Una nueva ligadura', Siglo méd., 1874, $21,717$.

264. - 'Método portugués para la cura de las heridas', ibid., 1874, 31, 810-11.

265. — 'El catgut antiséptico para las ligaduras', ibid., 1875, 22, 762-63.

266. - 'Los micrococus y las bacterias en las paredes de los hospitales', ibid., 1876, 23, 682.

267. ——, 'La medicación antiséptica', ibid., 1877, 24, 203-4.

268. —— 'El ácido salicílico como tópico', ibid., 1877, 24, 587.

269. —_ 'Cura antiséptica de Lister', ibid., 1878, 25, 9.

270. - 'Nuevo criterio para averiguar el valor relativo de los diversos antisépticos', ibid., 1878, 25, 75-78.

271. _- 'Acción del calor y de la desecación sobre la virulencia de los líquidos sépticos y sobre los organismos inferiores', ibid., 1878, 25, 257.

272. ㄴ 'Influencia de los descubrimientos de Pasteur en los progresos de la Cirugia', ibid., 1878, 25, 364-66.

273. — 'Nuevo antiséptico', ibid., 1878, 25, 444. 


\section{Juan Riera}

274. —_ 'La estopa purificada y antiséptica', ibid., 1878, 25, 513.

275. - 'El agua oxigenada en Cirugia', ibid., 1878, 25, 511-12.

276. - 'Resultado de 50 ovariotomias hechas por el método antiséptico', ibid., 1878, 25.

277. ——, 'Más sobre la cura de Lister', ibid., 1879, 26, 348-49.

278. 'Utilidad del método de Lister en las operaciones oculares', ibid., 1879, 26, $745-46$.

279. - 'Efectos y modo de obrar de las sustancias empleadas en las curas antisépticas'. ibid., 1879, 26, 796.

280. - 'Amputaciones antepiréticas, intrapiréticas y metapiréticas', ibid., 1880, 27, 74-75.

281. —- 'Los antisépticos y los antibióticos', ibid., 1880, 27, 394-95.

282. —_ 'Simplificación de la cura antiséptica', ibid., 1881, 28, 282-83.

283. - 'Las vendas de cautchuc en las afecciones quirúrgicas', ibid., 1881, 28, 525.

284. —— 'Los sucedáneos del ácido fénico', ibid., 1881, 28, 539-40.

285. —_ 'Cura de Lister en la extracción de la catarata', ibid., 1881, 28, 631-32.

286. - 'Cura antiséptica seca con los polvos de ácido bórico', ibid., 1883, 30, 91.

287. _- 'Modo de obrar los antisépticos en la cura de las heridas,' ibid., 1883, 30, 637.

288. 'Sesion del 7 de Febrero de 1880', An. R. Acad. Med., Madrid, 1880, 2, 36-39.

289. 'Sesion del 24 de Abril de 1880', ibid., 1880, 2, 211-15.

290. 'Sesion del 5 de Febrero de 1881', ibid., 1881, 3, 57-61.

291. 'Sesion del 12 de Febrero de 1881', ibid., 1881, 3, 61-65.

292. 'Sesion del 25 de Febrero de 1881', ibid., 1881, 3, 73-76.

293. 'Sesion del 5 de Marzo de 1881', ibid., 1881, 3, 76-79.

294. 'Sesion del 12 de Marzo de 1881', ibid., 1881, 3, 97-100.

295. 'Sesion del 26 de Marzo de 1881', ibid., 1881, 3, $100-4$.

296. 'Sesion del 9 de Abril de 1881', ibid., 1881, 3, 109-15.

297. 'Sesion del 23 de Abril de 1881', ibid., 1881, 3, 115-21.

298. 'Sesion de 7 de Mayo de 1881', ibid., 1881, 3, 125-37.

299. 'Sesion del 14 de Mayo de 1881', ibid., 1881, 3, 137-39.

300. 'Sesion del 21 de Mayo de 1881', ibid., 1881, 3, 139-41.

301. 'Sesion del 16 de Marzo de 1895', ibid., 1895, 15, 73-87.

302. 'Sesion del 30 de Marzo de 1895', ibid., 1895, 15, 107-9.

303. Simancas, E., 'Aplicación hecha por Lister, de la crin de caballo, en sustitución de los tubos de desagüe: sus ventajas y condiciones', An. Cienc. méd., Madrid, 1875, 5, 363-64.

304. Sisternas y Bruguera, ERnesto De, 'Un caso notable de Cirugía conservadora', Actas . . . Congreso Hispano-portugués, Madrid, 1899, pp. 92-97.

305. Sloker De LA Pola, Miguel, Anatomia quirúrgica y Traumatología Craneal . . . con un prólogo del doctor D. José Ribera y Sans, Madrid [n.d.].

306. Termosifon, 'Sobre el termosifon y esterilizador rápido del doctor Martín Gil de Málaga', An. int. Med. Cirug., Madrid, 1898, 27, 430-35.

307. Sotelo y OJeda, Francisco De Leon, 'La antisepsia y las operaciones', Siglo méd., $1890,37,425-26$.

308. SUÑ̃ MoLIST, LuIs, 'Contribución al estudio del método antiséptico en la llamada fiebre puerperal', Gac. méd. catal., 1881, 1, 233-35.

309. Tapia y Serrano, Manuer, Notas de Patología quirúrgica general, Madrid, 1891.

310. Terrades, Francisco, 'Miguel Fargas', Homenagem á Escola Ginecológica-Obstétrica da Universidade de Barcelona, 1958, pp. 23-30.

311. Toledo, E., 'Desarrollo y evolución del método antiséptico', Revta Med. Cirug. práct., Madrid, 1890, 27, 274.

312. TOMAS MonTSERRAT, José, La obra médico-quirúrgica de Juan Creus y Manso, Valencia, 1967. 


\section{The Dissemination of Lister's Teaching in Spain}

313. Trias Pujol, J., 'El doctor Cardenal, maestro', An. R. Acad. Med. Cirug., Barcelona, 1928, 10-14.

314. Truax, RHODA, Joseph Lister, Father of Modern Surgery, London, 1947.

315. TuRner, A. Logan, Joseph, Baron Lister, Edinburgh, 1927.

316. Ustariz, José, 'Las curas con el algodón', An. Cienc. méd., Madrid, 1876, 164-69.

317. —_, 'Clínica quirúrgica', Siglo méd., 1879, 26, 25-27.

318. - 'Las curas de las heridas', An. Cienc. méd., Madrid, 1877, 2 (3), 161-65.

319. _ 'Dos casos de operación de Estlander por supuración crónica de la pleura', Actas . . . Congreso Hispano-portugués, Madrid, 1899, pp. 187-91.

320. 'Valor comparativo de la sepsis y antisépsis en Cirugía ocular' (Congreso de CienciasMédicas de Barcelona, tema IX), Gac. méd. catal., 1891, 14, 105-10, 137-39.

321. 'Ventajas que ha reportado la Cirugía moderna al tratamiento de las enfermedades de los huesos', Ses. Acad. méd.-quir. esp., Madrid, 1882, 10, 178-79, 327, 423-24, 470-71, 520-21.

322. Verdes Montenegro, José, Nuestros Hombres de Ciencia, Madrid, 1889.

323. WRENCH, G. T., Lord Lister, his Life and Work, London, 1913.

324. ZejIN, Paris (trans.), 'Lecciones de Clínica quirúrguca' (de Nussbaum), Siglo méd., 1886, 33, 774-75.

325. Zimmerman, Leo M., and Veith, IlzA, Great Ideas in the History of Surgery, Baltimore, 1961. 